\title{
Adaptive thermogenesis in adipocytes: Is beige the new brown?
}

\author{
Jun $\mathrm{Wu}^{1,2}$ Paul Cohen, ${ }^{1,2,3}$ and Bruce M. Spiegelman ${ }^{1,2,4}$ \\ ${ }^{1}$ Dana-Farber Cancer Institute, ${ }^{2}$ Department of Cell Biology, Harvard Medical School, Boston, Massachusetts 02115, USA; \\ ${ }^{3}$ Cardiovascular Division, Department of Medicine, Brigham and Women's Hospital, Harvard Medical School, Boston, \\ Massachusetts 02115, USA
}

\begin{abstract}
One of the most promising areas in the therapeutics for metabolic diseases centers around activation of the pathways of energy expenditure. Brown adipose tissue is a particularly appealing target for increasing energy expenditure, given its amazing capacity to transform chemical energy into heat. In addition to classical brown adipose tissue, the last few years have seen great advances in our understanding of inducible thermogenic adipose tissue, also referred to as beige fat. A deeper understanding of the molecular processes involved in the development and function of these cell types may lead to new therapeutics for obesity, diabetes, and other metabolic diseases.
\end{abstract}

The epidemic of obesity and type 2 diabetes presents a serious challenge to scientific and biomedical communities worldwide. While this epidemic was first obvious in the United States and other highly developed countries of Europe, it has spread across Asia, Africa, and Oceania. The purpose of this review is not to review all of the causes of these problems; clearly, increased access to foods high in caloric density and decreased physical movement have played important roles (Doria et al. 2008; Guilherme et al. 2008; Saltiel 2012).

The most important single idea in the field of metabolic disease is the concept of energy balance. This means that, with the rare exception of malabsorption of nutrients, an animal cannot gain or lose weight unless there is an imbalance between food intake and energy expenditure. When energy intake chronically exceeds energy expenditure, weight gain and obesity result. This excess weight is stored in adipose tissue, which consists of fat cells, or adipocytes, which have an incredible capacity for storing surplus energy in the form of lipid. This tissue is not just a passive storage depot, but also an endocrine organ, secreting molecules like leptin that can regulate appetite and whole-body metabolism. In addition to these well-described energy-storing fat cells, adipocytes also exist that are highly effective at transforming chemical energy into heat. Brown adipocytes, which get their name

[Keywords: brown fat; beige fat; obesity; adaptive thermogenesis; UCP1] ${ }^{4}$ Corresponding author

E-mail bruce_spiegelman@dfci.harvard.edu

Article is online at http://www.genesdev.org/cgi/doi/10.1101/gad.211649.112. from their high number of iron-containing mitochondria, are specialized to dissipate energy in the form of heat, a process called nonshivering thermogenesis. The thermogenic gene program of classical brown and beige fat cells (those brown cells that can emerge in white fat depots under certain conditions) can increase whole-body energy expenditure and therefore can protect against obesity and diabetes. This role of brown (and now beige) adipose cells in increasing whole-body metabolic rates has driven much of the interest in these cell types.

This review describes recent advances in our understanding of the development and function of both classical brown and beige fat cells. There has been an explosion of data identifying new pathways that activate these thermogenic cells; which avenues might prove useful in humans underlies the interest of our group and many others in this area. The final section of this review speculates on future prospects for brown and beige fat-based therapies in humans.

\section{Brown adipose tissue (BAT)}

Brown adipose was first described in small mammals and infants as an adaptation to defend against the cold. It was originally referred to as the hibernating organ due to its function in maintaining body temperature in hibernating animals (Hatai 1902; Rasmussen 1923; Cannon and Nedergaard 2004).

\section{Uncoupling protein 1 (UCP1) and thermogenesis}

Classical BAT is typically located in the interscapular region and is most easily detected in infants and small mammals. It is referred to as "classical" in distinction from the inducible or beige adipocyte, which has unique molecular and developmental characteristics (discussed below in this review; see also Table 1). Both types of thermogenic adipocytes can increase energy expenditure through the uncoupling of oxidative metabolism from ATP production. This is a key function of UCP1. This long chain fatty acid-activated protein, highly selective for brown and beige adipose cells, sits in the inner membrane of mitochondria and catalyzes a proton leak across the inner membrane, dissipating the electrochemical gradient that has been generated via the electron transport 
Table 1. Similarities and differences between brown and beige fat

\begin{tabular}{|c|c|c|}
\hline Characteristics & Brown fat & Beige fat \\
\hline Species & $\begin{array}{l}\text { Small rodents } \\
\text { (mice, rats) } \\
\text { Human infants }\end{array}$ & $\begin{array}{l}\text { Small rodents } \\
\text { (mice, rats) } \\
\text { Cats } \\
\text { Human adults }\end{array}$ \\
\hline $\begin{array}{c}\text { Anatomical } \\
\text { location }\end{array}$ & $\begin{array}{l}\text { Interscapular } \\
\quad \text { depot } \\
\text { Perirenal depot } \\
\text { Axial depot }\end{array}$ & $\begin{array}{l}\text { Inguinal subcutaneous } \\
\text { depot }\end{array}$ \\
\hline $\begin{array}{l}\text { Development } \\
\text { origin }\end{array}$ & $\mathrm{Pax}^{+} / \mathrm{Myf5}^{+}$ & Pax $7^{-} / M_{y f 5}{ }^{-}$ \\
\hline Morphology & Multilocular & Unilocular/multilocular \\
\hline Basal UCP1 & High & Low \\
\hline Stimulated UCP1 & High & High \\
\hline Thermogenic & Yes & Upon stimulation \\
\hline Anti-obesity & Yes & Yes \\
\hline
\end{tabular}

Factors regulating brown and beige adipocytes and the responses to secreted molecules of these two types of fat cells are listed in Tables 2 and 3.

chain (ETC) (Krauss et al. 2005; Bartelt et al. 2011; Fedorenko et al. 2012). In most cells lacking UCP1, this proton gradient can only be dissipated through the formation of ATP through complex V (ATP synthase) in the ETC. When ATP is abundant in most cells, electrons can no longer easily enter the ETC, and fuel oxidation in the mitochondria is halted. The "short circuit" in the proton gradient caused by UCP1 means that fuel oxidation can be accelerated and is not limited by saturating concentrations of ATP. Hence, all of the biochemical steps of mitochondrial fuel oxidation (Krebs cycle and ETC) are accelerated, and the inherent inefficiencies in their reactions result in heat production.

Thermogenesis is facilitated by multilocular lipid stores (meaning many lipid droplets) and the extremely high mitochondrial content of brown adipocytes. It is also promoted by the extensive vascular and nerve supply to this tissue. Catecholamines released by sympathetic nerve terminals act on $\beta$-adrenergic receptors to stimulate BAT thermogenesis. Recently, it has also been suggested that catecholamines secreted by a certain subtype of macrophages can activate brown and beige fat in mice (Nguyen et al. 2011). Sympathetic signaling is increased in the cold, and chronic cold exposure results in the activation and expansion of BAT (Klingenspor 2003). Moreover, in the absence of $\beta$-adrenergic signaling, mice are unable to maintain their core temperature (Bachman et al. 2002). Constitutive $\beta$-adrenergic agonism can have the same effect on BAT. This can be seen in pathological states with catecholamine-secreting tumors or induced pharmacologically with $\beta$-adrenergic agonists. BAT activity is also regulated by endocrine inputs from thyroid hormone, among others (Bianco 2011).

\section{Anti-obesity effects of brown fat-mediated adaptive thermogenesis}

While brown fat was first noted for its ability to protect animals from hypothermia (Smith and Horwitz 1969), the last 20 years have seen the anti-obesity/diabetes role of brown fat become clear. Earlier physiological studies had shown that caloric excess itself can stimulate brown adipose expansion and thermogenesis as an adaptation to maintain body weight. This process, known as dietinduced thermogenesis, is mediated by BAT and UCP1 (Rothwell and Stock 1997). In the absence of UCP1, mice are prone to dietary obesity. Genetic ablation of brown fat with a UCP1 promoter-driven toxigene (Lowell et al. 1993) first illustrated the protection these tissues afforded against obesity and diabetes. It is important to note that these protective effects were observed in mice raised at ambient temperatures and did not require exposure to either cold or thermoneutral temperature to elicit the differences between control and mutant animals. Ablation of UCP1 with standard knockout technology generated mice that were very susceptible to hypothermia but had no propensity to develop obesity or diabetes when raised at ambient temperatures (Enerback et al. 1997). Later work illustrated that this was because the UCP1 knockout mice shiver extensively, and most of the systemic effects of the ablation on energy metabolism were overwhelmed by the sustained shivering. When the UCP1 knockout mice were raised under thermoneutral conditions, they gained more weight and fat than their control littermates (Feldmann et al. 2009). This confounding effect of shivering was presumably not seen in the earlier brown fat ablations because the loss of UCP1 and UCP1-positive cells was not as complete with the toxigene, compared with that in the UCP1 knockout mice.

Since uncoupled thermogenesis is driven by oxidative metabolism, BAT is highly active metabolically. Its preferred fuel source is lipid, but it also actively takes up glucose, which is presumably the reason it is detectable by fluoro-deoxy-glucose (FDG)-positron emission tomography (PET) imaging. By relying on these fuel stores, activation of BAT has anti-obesity as well as glucoseand lipid-lowering effects, a property that might be exploited for therapeutic benefits (Bartelt et al. 2011).

\section{Transcriptional control of brown fat development and function}

Despite having such a different physiological role from white adipose, brown adipocytes share many core molecular components with white fat cells. They both require the transcription factor PPAR $\gamma$ for their development and function. Interestingly, however, mice with a dominantnegative mutation of PPAR $\gamma(\mathrm{P} 465 \mathrm{~L})$ have defects in BAT but not white adipose tissue (WAT) function (Gray et al. 2006). Members of the C/EBP transcription factor family $(\mathrm{C} / \mathrm{EBP} \alpha, \mathrm{C} / \mathrm{EBP} \beta$, and $\mathrm{C} / \mathrm{EBP} \delta$ ) are involved in both white and brown adipogenesis. Overexpression of $\mathrm{C} / \mathrm{EBP} \beta$ in certain white adipocytes induces the expression of brown fat cell genes, although its role in both brown and white adipogenesis suggests that it does not specifically regulate cell fate (Karamanlidis et al. 2007).

The molecular basis for the unique program in brown adipose remained unknown until the identification of 
PGC-1, a cold-induced PPAR $\gamma$-binding partner (Puigserver et al. 1998). PGC-1 (now PGC-1 $\alpha$ ) expression is activated by the PKA-CREB pathway, which is downstream from the $\beta$-adrenergic receptor (Herzig et al. 2001). The PGC-1 family is now known to exist in three isoforms: PGC- $1 \alpha$, PGC-1 $\beta$, and PRC. Furthermore, there are multiple splice variants of each, and the specific functions of these are still being elucidated (Ruas et al. 2012). PGC-1 $\alpha$ is expressed most highly in the kidney, liver, and muscle, tissues high in oxidative metabolism. This makes sense physiologically, as PGC- $1 \alpha$ is a dominant regulator of mitochondrial biogenesis and oxidative metabolism (Lin et al. 2005). PGC- $1 \alpha$ regulates thermogenesis by inducing the expression of UCP1 and key enzymes of the mitochondrial respiratory chain. Ectopic expression of PGC- $1 \alpha$ in white adipocytes robustly induces this gene program (Puigserver et al. 1998; Tiraby et al. 2003). Mice with a whole-body deletion of PGC-1 $\alpha$ have impaired cold-induced thermogenesis yet are surprisingly lean and resistant to dietary obesity due to centrally mediated hyperactivity (Lin et al. 2004). A cell-autonomous role for PGC-1 $\alpha$ in brown adipocytes was demonstrated by the generation of immortalized PGC-1 $\alpha$-null brown fat cell lines. This study demonstrated that PGC-1 is required for basal and cAMP-induced mitochondrial biogenesis and thermogenesis. However, PGC-1 $\alpha$-null brown adipocytes differentiate normally without alteration in numerous brown fatselective genes, indicating that it is not a determinant of brown adipocyte identity per se (Uldry et al. 2006).

While many factors besides the PGC-1s have been identified as regulators of brown fat development and function (see more discussion in "Multiple Genetic Models Have Shown Modified Adaptive Thermogenesis Capacity in Brown/Beige Fat" below), none had been shown to specifically confer brown fat cell identity until 2007. In an effort to identify such a factor, the expression level of all known and predicted transcriptional components in the mouse genome was surveyed (Seale et al. 2007). PRDM16 was one of three factors enriched in classical brown fat relative to WAT. PRDM16 was shown to be sufficient and necessary for the brown fat phenotype in cell culture models and sufficient to promote browning in visceral fat under $\beta$-adrenergic stimulation (Seale et al. 2007). PRDM16 was originally described as being located at a chromosomal breakpoint in acute myeloid leukemia (Mochizuki et al. 2000; Nishikata et al. 2003). It contains an $\mathrm{N}$-terminal proline-rich domain, $\mathrm{N}$-terminal and C-terminal zinc finger domains, and a SET domain, a domain often associated with histone lysine methyltransferase activity. A shorter form of PRDM16 has been detected in adult T-cell leukemia cells and in Northern blots from a number of mouse tissues (Yoshida et al. 2004; Seale et al. 2007). Whether these shorter forms are functionally relevant in brown adipose biology remains unknown.

When ectopically expressed in mesenchymal fibroblasts with no specific brown or white fat characteristics, PRDM16 induced the full molecular program of brown adipose cells (Seale et al. 2007). Specifically, PRDM16 induced the expression of thermogenic genes, mitochondrial components, and other brown fat identity genes; PRDM16 also repressed the expression of several white fat-specific genes. Examination of these cells showed increased mitochondrial content as well as enhanced uncoupled respiration, consistent with the formation of fully functional brown adipose. Furthermore, introduction of PRDM16 into PPAR $\gamma$-expressing fibroblasts permitted the generation of ectopic brown fat, which could be transplanted in vivo (Seale et al. 2007).

Interestingly, mutation in the DNA-binding domain of PRDM16 did not impair its ability to induce the brown fat phenotype, suggesting that it acts as a transcriptional coregulator in this context. Further studies showed that PRDM16 binds and coactivates PGC- $1 \alpha$, PGC-1 $\beta$, and PPAR $\gamma$ (Kajimura et al. 2008; Seale et al. 2008). To better understand how PRDM16 specifically directs a brown fat gene program while repressing white fat genes, the PRDM16 protein complex was purified from fat cells. This complex was found to contain the proteins CtBP-1 and CtBP-2, which can repress gene expression. On the other hand, recruitment of PGC- $1 \alpha$ and PGC-1 $\beta$ to PRDM16 displaces the CtBPs and permits coactivation of the brown fat program (Kajimura et al. 2008).

\section{'Browning' of the white adipose depots and beige adipocytes}

\section{The 'browning' of WATs}

The major white and brown adipose depots are located in anatomically different regions in both rodents and humans. However, it was reported almost 30 years ago that some multilocular, UCP1-positive fat cells exist within certain WATs in mice, rats, and cats. Furthermore, these cells became more prominent upon prolonged stimulation by cold (Young et al. 1984; Loncar et al. 1986, $1988 a, b)$. Similar phenomena were later observed in rodents treated with $\beta 3$-adrenergic receptor agonists that elevate intracellular cyclic AMP, like CL316, 243 (Cousin et al. 1992).

Interestingly, it has been reported that distinct genetic loci control the number of UCP1-positive cells in the white and classical brown fat depots in rodents /Guerra et al. 1998; Koza et al. 2000; Coulter et al. 2003; Xue et al. 2005, 2007). These experiments were carried out using AXB recombinant inbred (RI) strains of mice derived from the $\mathrm{B} 6$ and A/J parent strains. The "browning" responses to $\beta 3$-adrengergic receptor agonists in white adipose depots, and the retroperitoneal fat in particular, varied significantly among these RI strains. Quantitative trait locus (QTL) analyses showed that certain genetic variations have a significant impact on UCP1 induction in white fat, whereas they have a minimal effect on the interscapular brown fat. While no genes have yet been identified here, this has theoretically offered an experimental approach toward identifying regulators of this biological process. This also suggests that this process might be under genetic control in larger mammals, such as humans. 


\section{Two types of thermogenic adipocytes}

Gene expression profiling experiments had previously shown that classical brown fat cells from the interscapular region expressed certain genes typically found in skeletal muscle cells (Timmons et al. 2007). Direct evidence illustrating a developmental link between brown fat and skeletal muscle and that there were two different types of thermogenic fat cells came in Seale et al. (2008). To establish the requirement for PRDM16 in brown adipocytes, Seale et al. (2008) knocked down PRDM16 expression with an shRNA in primary brown fat cultures and found that typical skeletal muscle genes were induced in these cells. Moreover, these cells took on a dramatic, myotube-like morphology, showing periodic twitching in the cell culture dish. Lineage tracing experiments in vivo, marking myogenic factor 5 (Myf5)expressing progenitors, were performed to establish the developmental origin of the classical brown fat cells. Myf5 has been previously thought to only be expressed in committed precursors that give rise to skeletal muscle. These experiments (Seale et al. 2008) showed that brown fat cells in the interscapular and perirenal depots originate from the same or similar progenitors as skeletal muscle. In contrast, the $\mathrm{UCP} 1^{+}$fat cells that arise in classical white adipose depots under prolonged $\beta$-adrenergic stimulation definitely come from a non-Myf5-derived cell lineage.

The common origin of brown fat and skeletal muscle was further confirmed and refined in a lineage tracing experiment (Lepper and Fan 2010) using timed activation of a marker gene driven by Pax7. The time point at which precursors between skeletal muscle and brown fat diverge was pinpointed between embryonic day 9.5 (E9.5) and E11.5. A more recent study confirmed that classical brown fat (interscapular and perirenal) comes from a $\mathrm{Myf5}^{+}$ lineage but also suggested that at least some adipocytes from a broader range of fat depots may arise from the Myf5 lineage (Sanchez-Gurmaches et al. 2012). Importantly, all of these data illustrate that the "brown" fat cells emerging in white depots are from a completely different cell lineage than classical brown fat cells (Fig. 1).

\section{Identification and isolation of beige adipocytes}

While classical brown fat cells have been isolated, immortalized, and studied for many years, beige fat cells had, until recently, never been isolated or cloned. In fact, it had been suggested that the "brown conversion" of white fat could be an inherent property of most or all white fat cells and that this "transdifferentiation" may not be due to the presence of a distinct cell type with this predisposition (Himms-Hagen et al. 2000; Cinti 2002). While the potential for this kind of transdifferentiation has not been definitively disproven, several lines of direct evidence in support of the existence of beige precursors in white depots have been published in recent years.

Beige clonal cell lines and the isolation of beige precursors To circumvent the ambiguities inherent in the interpretation of data from studies of heterogeneous primary cell cultures and adipose tissues in vivo, we

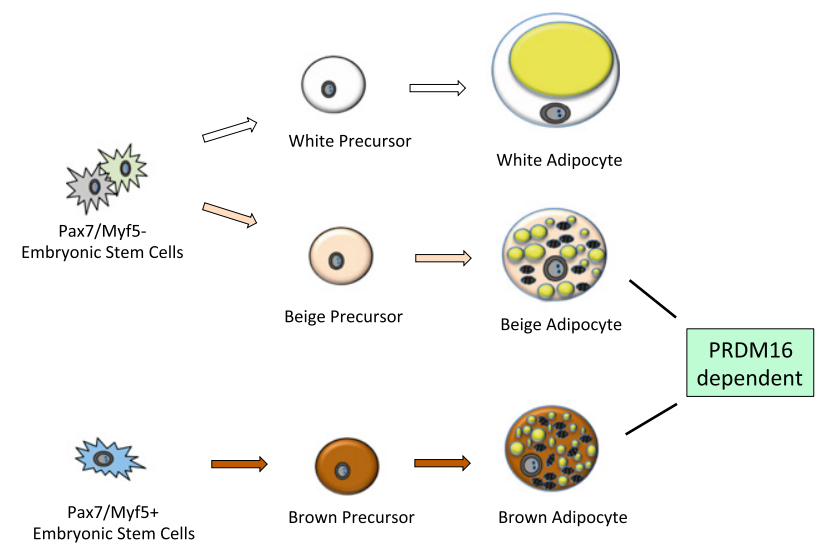

Figure 1. Origins of fat cells. At least three types of precursors give rise to white, beige, and brown adipose cells separately. Precursors for brown adipocytes developmentally originate from dermomyotome and express Pax7 and Myf5. White and beige adipocytes come from two distinct populations of precursors of Pax7- and Myf5-negative lineages. While PPAR $\gamma$ is essential for adipogenesis of all fat cells, various transcriptional components play different roles in the development, commitment, and differentiation of white, beige, and brown fat, and PRDM16 has been shown to play an important role in regulating both brown and beige fat (for details, see the text).

subcloned multiple preadipose cell lines from immortalized stromal cultures derived from either the subcutaneous white fat or the interscapular brown fat of mice (Wu et al. 2012). Clustering analysis of gene expression patterns suggested that a subgroup of the subcutaneous (inguinal depot) lines had a gene expression pattern more similar to the classical brown fat cell lines than to the other inguinal cell lines. This strongly suggested that a distinct type of precursor cell could give rise to beige fat cells, and these clonal cell lines offered a "pure" system to investigate the molecular signature and distinct functions of this new type of fat cell. Beige fat cells have a very low basal level of UCP1 (roughly equivalent to the immortalized white cells from the same mice) but can robustly respond to cAMP to activate a thermogenic program to levels similar to those seen in the brown cell lines from the classical interscapular depot (Fig. 2). Perhaps most importantly, this study illustrated that the UCP1 ${ }^{+}$cells detected in the supraclavicular region of healthy human adults have a molecular phenotype that is much more similar to murine beige fat cells rather than brown fat cells (see detailed discussions in "Human Brown and Beige Fat" below).

Brown in white (brite) cells The effects of thiazolidinediones (TZDs) and other PPAR $\gamma$ agonists on mitochondrial biogenesis and respiration in WATs have been well documented (Fukui et al. 2000; Laplante et al. 2003; Wilson-Fritch et al. 2003, 2004; Vernochet et al. 2009). Many hypotheses have been proposed to explain this phenomenon. It remains unknown whether TZDs' effects on mitochondrial biogenesis and adaptive thermogenesis 


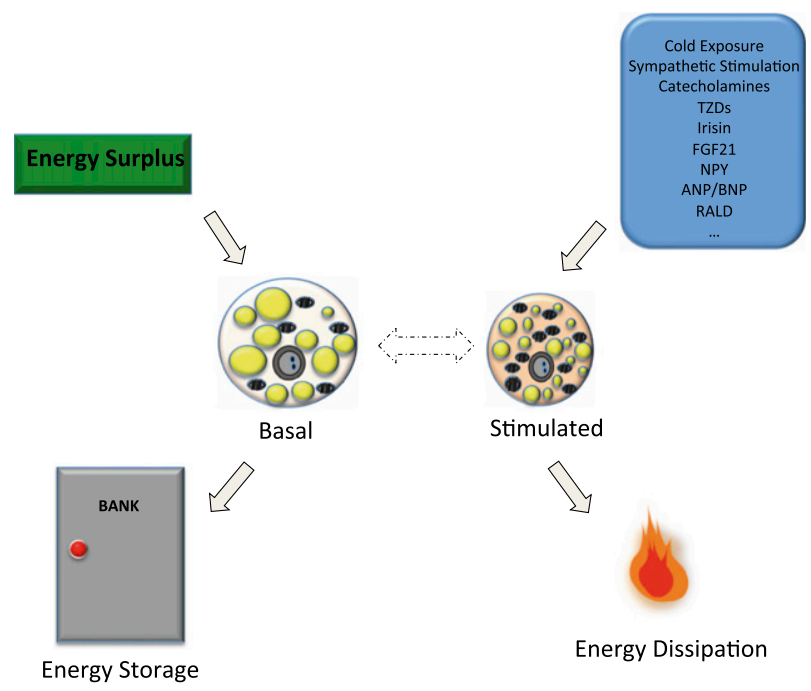

Figure 2. Dual functions of beige fat cells. Beige fat cells have a very low basal level of UCP1 but can robustly respond to cAMP to activate a thermogenic program to levels similar to those seen in the brown cells. When energy intake exceeds energy expenditure, the surplus energy can be stored in beige fat cells in the form of lipid, and beige fat cells take on a more "white" morphology. Many stimuli-including cold, sympathetic stimulation, TZDs, and hormones (including recently identified exercised induced polypeptide irisin)—can activate beige fat cells and result in increased energy dissipation.

contribute directly to the improvement of systemic insulin sensitivity in vivo.

Chronic treatment of primary precursors from the visceral WAT depot (epididymal) with PPAR $\gamma$ agonists showed that only a subpopulation of these precursors can attain a "brown"-like phenotype (Petrovic et al. 2010). The expression levels of previously described markers for different adipose depots were investigated (Gesta et al. 2006). In a follow-up study, the various responses to stimulation of the adipocytes in different depots were further investigated (Walden et al. 2012). From these studies, the investigators proposed the existence of a subtype of precursor that gives rise to $\mathrm{UCP} 1^{+}$adipocytes in white adipose depots and named these cells "brite" fat. Although further experimental evidence is needed, it is tempting to hypothesize that beige and brite cells are the same type of cells in vivo.

The mechanism by which PPAR $\gamma$ agonists induce brown remodeling appears to involve post-translational modification of PPAR $\gamma$. Agonist treatment was shown to lead to deacetylation of PPAR $\gamma$, which is dependent on the NADdependent deacetylase SirT1 (Qiang et al. 2012). Either gain of function of SirT1 or loss of function of its inhibitor, Dbc1, results in deacetylation of PPAR $\gamma$ and induction of thermogenic gene expression. This process is mediated by increased recruitment of PRDM16 to deacetylated PPAR $\gamma$.

Adipose tissue stem cells (ASCs) with thermogenic potential Even though the definition of ASCs is still presently being debated among experts in the field, a significant amount of knowledge on adipocyte biology has been generated from related studies. The recent progress in this area has been reviewed elsewhere (Cawthorn et al. 2012), so this review only discusses the studies that focus on ASCs with thermogenic potential.

Subpopulations of adipose progenitors have been isolated using different combinations of cell surface markers from enzyme-digested adipose tissue and skeletal muscle (Rodeheffer et al. 2008; Joe et al. 2010; Uezumi et al. 2010). The cell surface markers in these studies were largely selected based on expression levels in stem cell populations derived from other tissues, including CD31 (an endothelial marker), CD45 (a pan-hematopoietic marker), and SM/C-2.6 (a satellite cell marker; precursor for myotubes), among others. The identity of each subpopulation from fluorescence-activated cell sorting (FACS) was tested empirically with functional assays for adipogenesis and adaptive thermogenesis. Friedman's group (Rodeheffer et al. 2008) first showed that precursors from the murine white adipose stromal fraction $\left(\mathrm{Lin}^{-}: \mathrm{CD} 29^{+}: \mathrm{CD} 34^{+}: \mathrm{Sca}-1^{+}: \mathrm{CD} 24^{+}\right)$are highly adipogenic under both in vitro and in vivo conditions. Adipogenic subpopulations (CD31-:CD45 ${ }^{-}: \mathrm{SM} / \mathrm{C}-2.6^{-}: \mathrm{PDGFR} \alpha^{+}$) were also isolated from skeletal muscle (Uezumi et al. 2010). However, whether these populations respond to stimulation and activate a thermogenic program was not tested in either study. Another subpopulation $\left(\mathrm{Sca}-1^{+}\right.$: $\mathrm{CD}_{4}^{-} \mathrm{:Mac1}^{-}$, referred to as ScaPCs) can be isolated from fractioned interscapular brown fat, subcutaneous white fat, and skeletal muscle and can attain brown-like phenotypes when treated with bone morphogenetic protein 7 (BMP7) (for more on BMPs, see "Secreted Molecules That Activate BAT and/or Induce Beiging in WAT" below) (Schulz et al. 2011). A bipotential adipogenic subpopulation $\left(\mathrm{PDGFR} \alpha^{+}: \mathrm{Sca}-1^{+}: \mathrm{CD} 34^{+}\right.$; so-called PDGFR $\alpha^{+}$ cells) has recently been proposed (Lee et al. 2012). Upon $\beta$-adrenergic stimulation, there is a significant proliferation of PDGFR $\alpha^{+}$in epididymal (visceral) WAT in mice, whereas in high-fat diet-challenged mice, the PDGFR $\alpha^{+}$ cells gave rise to unilocular white fat cells. Since these subpopulations from primary ASC cultures are themselves heterogeneous, the molecular identity of these precursors (being brown, beige, or something else, for example) remains elusive.

\section{Multiple genetic models have shown modified adaptive thermogenesis capacity in brown/beige fat}

The number of studies that describe genetic models with an altered development and/or function of brown and beige fat has been increasing at a remarkable rate in recent years. Due to space limitations, we are not able to discuss all of these studies here, but we highlight a few representative reports. A more comprehensive list is summarized in Table 2.

\section{Cyclooxygenase-2 (Cox2)}

COX-2 is a rate-limiting enzyme in prostaglandin (PG) synthesis and has recently been shown to play a role in regulating the recruitment and activation of beige fat 
Table 2. Factors shown to affect brown and/or beige adipocytes' development and function

\begin{tabular}{|c|c|c|c|c|}
\hline Factors & Brown fat & Subcutaneous fat & Visceral fat & References \\
\hline 4E-BP1 & - & + & - & Tsukiyama-Kohara et al. 2001 \\
\hline ActRIIB & + & $\sim$ & + & Fournier et al. 2012; Koncarevic et al. 2012 \\
\hline AMPK & $\sim$ & $\sim$ & + & Vila-Bedmar et al. 2010 \\
\hline Androgen R & + & $\sim$ & + & Yanase et al. 2008 \\
\hline ATG7 & + & $\sim$ & + & Singh et al. 2009 \\
\hline ATGL & + & + & + & Ahmadian et al. 2011 \\
\hline Cancer cachexia & + & $\sim$ & + & Batista et al. 2012; Tsoli et al. 2012 \\
\hline $\mathrm{C} / \mathrm{EBP} \alpha$ & + & $\sim$ & + & Vernochet et al. 2009 \\
\hline $\mathrm{C} / \mathrm{EBP} \beta$ & + & $\sim$ & $\sim$ & Karamanlidis et al. 2007; Kajimura et al. 2009 \\
\hline Cidea & + & $\sim$ & $\sim$ & Zhou et al. 2003 \\
\hline Cox2 & - & + & + & Vegiopoulos et al. 2010 \\
\hline$\delta$-Opioid R & + & $\sim$ & $\sim$ & Czyzyk et al. 2012 \\
\hline Elovl3 & + & $\sim$ & + & Jakobsson et al. 2005; Zadravec et al. 2010 \\
\hline Enriched environment & + & + & + & Cao et al. 2011 \\
\hline Foxc2 & + & $\sim$ & + & Cederberg et al. 2001 \\
\hline FSP27 & + & + & + & Toh et al. 2008 \\
\hline GPR50 & + & $\sim$ & $\sim$ & Bechtold et al. 2012 \\
\hline GRK2 & + & $\sim$ & + & Vila-Bedmar et al. 2012 \\
\hline Hedgehog & + & $\sim$ & $\sim$ & Teperino et al. 2012 \\
\hline IGF1R/IR & + & + & + & Boucher et al. 2012 \\
\hline $\mathrm{IKK} \varepsilon$ & - & $\sim$ & + & Chiang et al. 2009 \\
\hline LRP6 & + & $\sim$ & $\sim$ & Liu et al. 2012 \\
\hline LXR & + & $\sim$ & + & Wang et al. 2008 \\
\hline MGL & + & $\sim$ & $\sim$ & Jung et al. 2012 \\
\hline miR-133 & + & + & $\sim$ & Trajkovski et al. 2012 \\
\hline miR-193b-365 & + & $\sim$ & $\sim$ & Sun et al. 2011 \\
\hline $\operatorname{miR}-196 a$ & $\sim$ & + & + & Mori et al. 2012b \\
\hline Myostatin & + & + & + & Jackson et al. 2012 \\
\hline NG2 & + & $\sim$ & $\sim$ & Chang et al. 2012 \\
\hline OMA1 & + & $\sim$ & $\sim$ & Quiros et al. 2012 \\
\hline p107 & $\sim$ & + & + & Scime et al. 2005 \\
\hline PGC- $1 \alpha$ & + & + & + & Puigserver et al. 1998; Kleiner et al. 2012 \\
\hline Plac8 & + & $\sim$ & $\sim$ & Jimenez-Preitner et al. 2011 \\
\hline PRCP & + & $\sim$ & $\sim$ & Jeong et al. 2012 \\
\hline PRDM16 & + & + & $\sim$ & Seale et al. 2008; Seale et al. 2011; Ohno et al. 2012 \\
\hline PRLR & $\sim$ & + & - & Auffret et al. 2012 \\
\hline PTEN & + & + & + & Ortega-Molina et al. 2012 \\
\hline PTP1B & $\sim$ & + & + & Klaman et al. 2000 \\
\hline $\mathrm{Rb}$ & + & $\sim$ & $\sim$ & Hansen et al. 2004 \\
\hline Renin-angiotensin system & + & $\sim$ & $\sim$ & Grobe et al. 2010 \\
\hline RIP140 & + & + & $\sim$ & $\begin{array}{l}\text { Leonardsson et al. 2004; Christian et al. 2005; } \\
\text { Powelka et al. } 2006\end{array}$ \\
\hline SFRP5 & $\sim$ & $\sim$ & + & Mori et al. 2012a \\
\hline Sirt1 & + & $\sim$ & $\sim$ & Qiang et al. 2012 \\
\hline SRC & + & $\sim$ & + & Picard et al. 2002 \\
\hline TFAM & + & + & $\sim$ & Vernochet et al. 2012 \\
\hline Them1 & + & $\sim$ & $\sim$ & Zhang et al. 2012 \\
\hline TNFR1 & + & $\sim$ & + & Romanatto et al. 2009 \\
\hline TRPM8 & + & $\sim$ & $\sim$ & Ma et al. 2012 \\
\hline TRPV4 & - & + & + & Ye et al. 2012 \\
\hline Twist-1 & + & $\sim$ & $\sim$ & Pan et al. 2009 \\
\hline VEGF & $\sim$ & $\sim$ & + & Lu et al. 2012 \\
\hline Wnt10b & + & $\sim$ & + & Kang et al. 2005; Wright et al. 2007 \\
\hline
\end{tabular}

$(+)$ The factor affects the thermogenic adipocytes in that depot; $(-)$ no effects; $(\sim)$ the potential regulation has not yet been investigated. For factors identified and characterized in heterogenous systems (for example, mouse embryonic fibroblasts), their specific contributions to different fat cell types await further studies. The effects of each factor on different fat depots in genetic-mutated rodent models may be caused by either direct regulation of adipocytes within that depot or systematic changes of overall adiposity.

cells in mice (Vegiopoulos et al. 2010). The expression level of COX-2 is induced upon sympathetic stimulation in both subcutaneous and intra-abdominal white fat tissues. In a mouse model with ectopic expression of
COX-2 in the skin, adaptive thermogenic genes are induced in WAT but not interscapular BAT. Conversely, loss or inhibition of COX-2 activity in vivo leads to a blunted response to $\beta 3$-adrenergic stimulation in WAT 
but not BAT. As a result of its regulatory role in "beiging," excess activity of COX-2 in vivo is sufficient to protect the transgenic mice from weight gain and associated hyperglycemia from a high-fat diet. Further studies are warranted to reveal the molecular mechanism by which local PG production can influence browning/beiging and systematic energy expenditure. The intriguing observation that COX-2 induces/activates $\mathrm{UCP}^{+}$cells in both subcutaneous and visceral WAT is consistent with the hypothesis that beige adipocytes/beige precursors exist in multiple WAT depots.

\section{FoxC2}

FoxC2 is a forkhead/winged helix transcription factor family member that regulates brown fat development. Transgenic expression of FoxC2 in WAT results in a brown fat phenotype with increased mitochondrial content and thermogenic gene expression (Cederberg et al. 2001; Kim et al. 2005). These transgenic mice are also insulinsensitive and resistant to dietary obesity. This effect is mediated by increased sensitization to the $\beta$-adrenergic receptor-cAMP-PKA pathway and seems to be due to direct induction of the RI $\alpha$ subunit of PKA by FoxC2 (Cederberg et al. 2001; Dahle et al. 2002). It remains unknown whether FoxC2 is genetically required for the brown fat phenotype.

\section{$I K K \varepsilon$}

It has been shown that a high-fat diet activates NF-кB in the adipose tissue and the liver. Deletion of ІкB kinase $\varepsilon$ $(\mathrm{IKK} \varepsilon)$, a direct downstream target of the NF- $\mathrm{B}$ pathway, increases energy expenditure and protects IKK $\varepsilon$ knockout mice from diet-induced obesity (Chiang et al. 2009). UCP1 expression is induced in the visceral fat (epididymal WAT) but remains similar to controls in the interscapular brown fat. The change in the WAT is consistent with an increased body temperature and oxygen consumption rate. The subcutaneous WAT was not investigated in this study. Future work on the development and function of beige fat in this model may provide insights for molecular mechanisms.

\section{$P G C-1 \alpha$}

PGC-1 $\alpha$ is a key nodal point in the thermogenic pathway. Broadly speaking, factors regulate this program either via direct action on PGC- $1 \alpha$ or, secondarily, by regulating cAMP-dependent gene expression. Both the retinoblastoma protein $(\mathrm{pRb})$ and the $\mathrm{Rb}$ family member p107 repress PGC-1 $\alpha$. Deletion of either factor in adipocyte precursors promotes a brown fat phenotype with increased expression of UCP1 and PGC-1 $\alpha$ (Hansen et al. 2004; Scime et al. 2005). The in vivo requirement for $\mathrm{pRb}$ in brown fat development has been uncertain, since $\mathrm{pRb}$ knockout is embryonic-lethal (Clarke et al. 1992; Jacks et al. 1992; Lee et al. 1992). A more recent study, however, addressed this question by deleting $\mathrm{p} 53$ and $\mathrm{pRb}$ specifically in mesenchymal cells. Prx1-Cre;p53 ${ }^{\text {flox/flox }}$ mice tended to develop osteosarcomas, whereas deletion of both $\mathrm{p} 53$ and $\mathrm{pRb}$ in mesenchymal cells resulted in the preferential formation of brown adipose-containing tumors called hibernomas (Calo et al. 2010). These in vivo findings indicate that $\mathrm{pRb}$ may modulate a cell fate choice between bone and brown adipose. The requirements of PGC-1 $\alpha$ itself in brown and beige fat development and function have been studied in mice with fatspecific deletion of PGC-1 $\alpha$ (Kleiner et al. 2012). The expression of thermogenic genes at ambient temperature is reduced in both subcutaneous and visceral white fat in the absence of PGC- $1 \alpha$, whereas brown fat function largely remains intact, possibly due to compensation from other brown-selective regulators (Kleiner et al. 2012).

\section{PRDM16}

PRDM16 plays a pivotal role in regulating brown fat cell fate and function [for details, see "Brown Adipose Tissue (BAT)" above]. The potential role of this molecule in modulating beige fat cell function was investigated in the fat-specific PRDM16 transgenic mouse model (Seale et al. 2011). Ectopic expression of PRDM16 in the adipocytes showed little effects in classical brown fat, possibly due to the relatively high basal expression in this depot. The thermogenic program is greatly induced in the subcutaneous white fat depots, but not the visceral, in the PRDM16 fat transgenic mice compared with the controls (Seale et al. 2011). A depot-dependent discrepancy between PRDM16 mRNA and protein levels was noted, likely caused by differential stability of PRDM16 in subcutaneous and visceral white adipose (Ohno et al. 2012).

The increased abundance of $\mathrm{UCP}^{+}$cells within the subcutaneous adipose protects PRDM16 fat transgenic mice against diet-induced obesity and significantly improves glucose tolerance (Seale et al. 2011). The therapeutic potential of PRDM16 can be explored by multiple approaches. "Engineered" brown fat cells with ectopic expression of both PRDM16 and C/EBP $\beta$ can actively uptake glucose in vivo after subcutaneous transplantation in rodents (Kajimura et al. 2009). It has been shown that PRDM16 expression can be regulated by microRNAs (Sun et al. 2011; Trajkovski et al. 2012). When treated with hemopoietin cocktail, PRDM16 is induced in human pluripotent stem cells (hPSCs), and these hPSCderived brown adipocytes showed thermogenic activation by adrenergic stimulation (Nishio et al. 2012).

\section{RIP140}

The nuclear receptor corepressor RIP140 also regulates brown adipose development and function. RIP140 directly binds to PGC- $1 \alpha$ and antagonizes its transactivation of thermogenic target genes (Hallberg et al. 2008). Overexpression of RIP140 in adipocytes represses expression of genes involved in mitochondrial biogenesis and oxidative metabolism (Leonardsson et al. 2004; Christian et al. 2005; Powelka et al. 2006). Conversely, deletion of RIP140 results in the appearance of brown-like adipocytes within WAT (Leonardsson et al. 2004). 


\section{Steroid receptor coactivator (SRC)}

The SRC family members also play a role in thermogenesis (Louet and O'Malley 2007). SRC-1/NcoA1 knockout mice have impaired adaptive thermogenesis, while SRC-2/TIF2 knockout mice demonstrate enhanced adaptive thermogenesis (Picard et al. 2002). The mechanism appears to be via effects on PGC- $1 \alpha$, as SRC-1 enhances coactivation of PPAR $\gamma$ by PGC- $1 \alpha$, whereas SRC-2 inhibits PPAR $\gamma-$ PGC- $1 \alpha$ interaction. SRC-3/pCip deletion results in increased mitochondrial content and brown adipose with anti-obesity and insulin-sensitizing effects (Louet et al. 2006; Coste et al. 2008). This too appears to be via effects on PGC- $1 \alpha$, as SRC-3 induces GCN5, which acetylates and inhibits PGC- $1 \alpha$ (Lerin et al. 2006).

\section{Transient receptor potential vanilloid 4 (TRPV4)}

The TRPV receptors are a family of ion channels. A chemical screen for small molecules that induce PGC- $1 \alpha$ expression in adipocytes revealed that TRPV4 negatively regulates the expression of PGC- $1 \alpha$, UCP1, and cellular respiration (Ye et al. 2012). In the same study, the investigators also uncovered that TRPV4 controls a program of proinflammatory genes that contributes to the development of insulin resistance. This dual role of TRPV4 in regulating the metabolic functions of adipocytes makes it a compelling target for drug development. In fact, mice treated with a TRPV4 antagonist showed elevated thermogenesis and were protected from diet-induced obesity, adipose inflammation, and insulin resistance.

\section{Secreted molecules that activate BAT and/or induce beiging in WAT}

Signaling molecules represent a straightforward link between basic research and clinical applications. A spectrum of these molecules has been reported to play a role in regulating brown or beige fat function in vivo (see Table 3).

\section{Cardiac natriuretic peptides (NPS)}

The NP family is comprised of atrial NP (ANP), brain NP (BNP, first identified in the porcine brain), and C-type NP (NP). ANP and BNP are predominantly released from the atria and ventricles, respectively, and are therefore called cardiac NPs. These peptides regulate natriuresis, body water, and ion homeostasis. The potential role of cardiac NPs in fat was suggested by the expression of NP receptors in adipose tissues (Sarzani et al. 1993, 1996) and later observations that NPs regulate lipolysis in adipose tissue, especially during exercise (Sengenes et al. 2000; Moro et al. 2004, 2006). A recent study showed that thermogenic programs are induced in ANP-treated human primary adipocytes in vitro. Moreover, BNP infusion in mice induces UCP1 expression in both BAT and inguinal subcutaneous WAT and increases system energy expenditure (Bordicchia et al. 2012). The browning/beiging effects of cardiac NPs are also supported by the analysis of mice with deletion of the NP clearance receptor (Nprc).
Table 3. Secreted molecules shown to affect brown and/or beige adipocytes' development and function

\begin{tabular}{lccl}
\hline & $\begin{array}{c}\text { Affects } \\
\text { classical } \\
\text { brown fat }\end{array}$ & $\begin{array}{c}\text { Affects } \\
\text { beiging }\end{array}$ & \multicolumn{1}{c}{ References } \\
\hline ANP/BNP & + & + & Bordicchia et al. 2012 \\
BMP7 & + & - & Tseng et al. 2008 \\
BMP8B & + & - & Whittle et al. 2012 \\
Catecholamines & + & + & Nguyen et al. 2011 \\
FGF16 & + & $\sim$ & Konishi et al. 2000 \\
FGF19 & + & $\sim$ & Fu et al. 2004 \\
FGF21 & + & + & See text \\
FNDC5/irisin & - & + & Bostrom et al. 2012 \\
GDF3 & $\sim$ & + & Shen et al. 2009 \\
NPY & + & + & Chao et al. 2011 \\
Orexin & + & - & Sellayah et al. 2011 \\
Rald & $\sim$ & + & Mercader et al. 2006; \\
& & & Ziouzenkova et al. \\
& & & 2007; Kiefer et al. \\
TZDs & & & 2012 \\
\hline
\end{tabular}

$(+)$ The molecule affects brown or beige adipocytes; (-) no effects; $(\sim)$ the potential regulation has not yet been investigated.

NP receptor A (NPRA) mediates the signals from ANP and BNP and generates the second messenger, cGMP, whereas the NPRC removes NPs from circulation. UCP1 is induced in all adipose tissues in the $\mathrm{Nprc}^{-/-}$mice compared with controls, and, furthermore, the ratio of NPRA/NPRC is increased in wild-type mice upon cold exposure. The detailed mechanism of how NPs regulate thermogenic programs remains unknown, but the p38/ MAPK pathway may be involved.

\section{Fibroblast growth factor 21 (FGF21)}

FGF21 is an endocrine hormone that belongs to the FGF family and has been shown to play an important role in regulating the fasting response in the liver (Kharitonenkov et al. 2005; Badman et al. 2007; Inagaki et al. 2007). More recently, FGF21 has been shown to play a role in adaptive thermogenesis in both BATs and WATs (Hondares et al. 2010; Fisher et al. 2012). FGF21 is secreted locally by adipose tissues under certain conditions such as cold, and this polypeptide regulates browning/beiging, at least in part, through stimulating accumulation of PGC- $1 \alpha$ protein (Fisher et al. 2012). The therapeutic potential of FGF21 is hindered by the fact that systematic administration of FGF21 promotes bone loss, possibly through PPAR $\gamma$ (Wei et al. 2012). However, local induction/ administration of FGF21 without increasing FGF21 in circulation remains an attractive avenue for therapeutics. Other members of the FGF family have also been reported to be involved in regulating energy expenditure in rodents (Konishi et al. 2000; Fu et al. 2004; Jonker et al. 2012).

\section{Fibronectin type III domain-containing 5 (FNDC5)/irisin}

It has been observed that resting metabolic rate (RMR) is increased over a prolonged period of time with both acute 
and long-term exercise training, and these effects have been believed to be mediated by increased lean tissue mass (Speakman and Selman 2003). Not until recently was it suggested that the beneficial effects of exercise may also come from changes in energy expenditure in both BAT and WAT (Xu et al. 2011). PGC-1 $\alpha$ is induced during exercise (Pilegaard et al. 2003; Russell et al. 2003) and regulates many exercise-related pathways in skeletal muscle (Lin et al. 2002; Sandri et al. 2006; Handschin et al. 2007; Wu et al. 2011). Muscle-specific ectopic expression of PGC-1 $\alpha$ increases whole-body energy expenditure and protects mice from age-related obesity (Wenz et al. 2009). Consistent with the hypothesis that the signal is transduced from skeletal muscle to adipose tissues in exercise, the subcutaneous WAT in musclespecific PGC- $1 \alpha$ transgenic mice shows elevated expression of UCP1. Global gene expression profiling was done to compare muscles of mice with elevated expression of PGC-1 $\alpha$ and wild-type controls. FNDC5 (also known as FRCP2 and PeP) was then predicted to be a secreted protein that was expressed at a higher level in skeletal muscle post-exercise or with ectopic PGC- $1 \alpha$ expression (Bostrom et al. 2012; Lecker et al. 2012). In vitro treatment of primary adipocytes with FNDC5 protein or adenoviral delivery of FNDC5 in vivo to the liver induces thermogenic gene expression, including UCP1 and Cidea, in the adipose cells/tissues. A cleaved form of FNDC5, named irisin, can be detected in both human and murine sera samples with increased amounts following exercise (Bostrom et al. 2012; Huh et al. 2012). It was later shown that beige fat preferentially responds to this polypeptide hormone, but the molecular mechanisms by which irisin activates beige fat remain elusive (Wu et al. 2012). Whether this new hormone contributes to the beneficial effects of exercise in other tissues and organs awaits further studies.

\section{Retinaldehyde dehydrogenase (Raldh)}

Raldh1 (also known as Aldhla1) is the rate-limiting enzyme that converts retinaldehyde (Rald) to retinoic acid. Deletion of Raldh in mice results in increased Rald levels and protection from dietary obesity and diabetes, as a consequence of increased energy expenditure (Ziouzenkova et al. 2007). In a follow-up study, Raldh was found to be enriched in visceral adipose tissue, and deficiency of this enzyme resulted in a brown fat-like phenotype in visceral white fat (Kiefer et al. 2012). This appears to be mediated by increased Rald levels, resulting in activation of the retinoic acid receptor, recruitment of PGC- $1 \alpha$, and increased UCP1 expression.

\section{Transforming growth factor- $\beta$ (TGF- $\beta$ ) and BMPs}

The role of the TGF- $\beta$ signaling pathway and proteins in the BMP families in adipocyte biology has been an exciting area (Jin et al. 2006; Zamani and Brown 2011; Yadav and Rane 2012). TGF- $\beta$ and its related proteins play an important role in regulating growth, development, and cell fate commitment in many cell types /Chen et al.
2004; Mullen et al. 2011). It has been observed that TGF- $\beta$ levels correlate with adiposity in both mice and humans (Samad et al. 1997; Alessi et al. 2000; Fain et al. 2005). $\mathrm{Smad}^{-1-}$ mice have increased mitochondrial biogenesis in the WATs and are protected from diet-induced obesity and diabetes (Yadav et al. 2011). Mesenchymal progenitor cells are committed to a brown cell fate upon BMP7 treatment, and adenoviral overexpression of BMP7 in mice increases energy expenditure and protects against dietinduced weight gain (Tseng et al. 2008). BMP8B, a brown fat-enriched $\mathrm{BMP}$, has recently been shown to activate thermogenesis in rodents (Whittle et al. 2012). BMP8B treatment potentiates brown adipocytes' response to norepinephrine and also acts on hypothalamus and alters central control of sympathetic activation of BAT. BMP8Bnull mice show decreased energy expenditure and gain more body weight despite reduced food intake (Whittle et al. 2012). Another example of the role of TGF $\beta$ signaling was demonstrated via administration of soluble activin receptor type IIB (ActRIIB) in mice. A recombinant protein of the extracellular domain of ActRIIB and the Fc fraction of human IgG was given to mice and led to increased expression of UCP1 and PGC-1 $\alpha$ in WAT and protection against diet-induced obesity (Koncarevic et al. 2012).

\section{Human brown and beige fat}

Several recent reviews have summarized studies of UCP1-positive cells in humans (Enerback 2010a; van Marken Lichtenbelt and Schrauwen 2011). Rediscovery of "thermogenic" UCP1-positive adipocytes in adult humans (Cypess et al. 2009; van Marken Lichtenbelt et al. 2009; Virtanen et al. 2009; Zingaretti et al. 2009) has presented a unique opportunity to counter obesity in humans. A growing body of data demonstrated that adaptive thermogenesis may play a rather significant role in human physiology.

The brown-selective and beige-selective markers identified from murine clonal cell lines provided a powerful tool to investigate the molecular identity of $\mathrm{UCP}^{+}$cells in human adults (Wu et al. 2012). Analyses of supraclavicular biopsies from two cohorts of healthy human adults reveal that beige markers are significantly enriched in the $\mathrm{UCP}^{+}$, so-called "BAT" samples in comparison with the neighboring "white" fat controls. Meanwhile, the expression level of brown-selective markers is comparable between $\mathrm{UCP}^{+}$and $\mathrm{UCP}^{-}$biopsy samples. This strongly suggests that these metabolically active cells are molecularly similar to murine beige adipocytes. This observation has been confirmed by two recent reports (Sharp et al. 2012; Lidell et al. 2013). Gene expression analyses of autopsy samples of multiple human fat depots suggest that the majority of $\mathrm{UCP}^{+}$fat cells in humans show beige fat characteristics instead of brown (Sharp et al. 2012). Studies of fat tissues from the interscapular region of human infants post-mortem confirmed that this depot in human infants is composed of classical brown adipocytes just like smaller mammals (Lidell et al. 2013). Most of the studies on human "brown" fat reported 
so far were actually done with the $\mathrm{UCP} 1^{+}$beige fat cells in the supraclavicular region of human adults. To avoid confusion, in this review, we refer to those cells as human brown/beige fat.

\section{Technical advances in detecting human brown/beige fat}

The existence of brown fat within the interscapular depot of human newborns and in adults with pheochromocytoma is well documented (Aherne and Hull 1966; Heaton 1972; Ricquier et al. 1982; Lean et al. 1986a,b). The recent rediscoveries of human "brown" fat were made possible by so-called metabolic imaging techniques, which involve the combination of 18 -fluoro-deoxy-glucose $\left({ }^{18} \mathrm{~F}\right.$ FDG), PET, and computed tomography (CT). The sensitivity of this technique is limited, and it only measures brown/beige fat activity by means of radioactive $\left[{ }^{18} \mathrm{~F}\right] \mathrm{FDG}$ uptake. It is highly likely that fatty acids in the plasma compete with glucose for cellular uptake, especially when adaptive thermogenesis is activated and there is an increased fuel demand. Therefore, PET/CT will underestimate true brown/beige fat activity in vivo.

Several alternative approaches have been proposed to locate, characterize, and quantitate brown/beige fat in vivo. One approach is to use blood oxygen level-dependent magnetic resonance imaging (BOLD MRI) to monitor the increase in oxygen consumption and consequent increase in blood deoxyhemoglobin levels following BAT activation (Khanna and Branca 2012). Another approach was designed based on the fact that activation of brown/beige fat is accompanied by mitochondrial thermogenesis. The retention of ${ }^{18} \mathrm{~F}$-FBnTP (a mitochondria-targeting voltage sensor-radiolabeled fluorobenzyltriphenyl phosphonium) was assayed as an indicator of brown/beige fat volume and function (Madar et al. 2011). A recent study describes contrast ultrasound $(\mathrm{CU})$ as a novel noninvasive approach to monitor and characterize the activation of BAT in rodents based on the change of blood flow into the tissue (Baron et al. 2012). It is reasonable to anticipate that other noninvasive, convenient, and sensitive measures will be developed as a better understanding of brown and beige fat biology is achieved.

\section{Metabolic functions of human brown/beige fat and its correlation with metabolic profiles}

In the past 4 years, many new reports revealed correlations between brown/beige fat function and metabolic homeostasis in humans. First of all, it has been noticed that there is more active brown/beige fat in women than in men (Au-Yong et al. 2009; Cypess et al. 2009; Lee et al. 2010; Pfannenberg et al. 2010). The sexual dimorphism in brown/beige fat activity is also reported in rodents (Rodriguez-Cuenca et al. 2002). While the molecular mechanism is still under investigation, the gender differences and the hormonal environment should definitely be taken into consideration for any potential therapeutic modulation of brown/beige fat activity in humans. However, it is worth noting that serum testosterone levels inversely correlate with abdominal obesity in men, and androgen receptor-null male mice develop late-onset obesity, possibly due to reduced expression of UCP1 (Yanase et al. 2008). The detected brown/beige fat activity correlates inversely with the age of tested subjects (Ouellet et al. 2011), is rather low in obese subjects, and is increased after weight loss from bariatric surgery (Vijgen et al. 2011, 2012). An interesting observation is that unlike what has been observed in rodents, systemic administration of a sympathomimetic substance does not induce detectable activity in human brown/beige fat (Cypess et al. 2012; Vosselman et al. 2012). Since the doses in these studies are comparable with the physiological level of sympathetic tone induced by mild cold exposure, where brown/beige fat activity is activated, a definitive explanation for this discrepancy remains elusive. Regardless of the molecular mechanism for this phenomenon, serious side effects associated with higher doses of sympathomimetic substance preclude this approach from direct clinical use. The causal or even clear correlative relationship between brown/beige fat function and overall metabolic fitness in humans awaits a better understanding of the basic biology of these thermogenic cells and improved analyzing tools to detect and quantitate brown/beige fat in humans.

\section{Open questions and future directions}

The explosive progress in brown fat has opened up many exciting prospects for the future in both basic science and therapeutics. We now know that there are two types of distinct thermogenic adipose cells: brown and beige. However, it is entirely possible that there are yet more important thermogenic cell types to be discovered. For example, it is known that the "brown" cells that develop in visceral fat are not classical Myf5 lineage-derived cells, but it is not yet clear whether these are beige cells or yet another distinct cell type. Another important question relates to the neural connections of the nonclassical brown fat cells, beige or other. We know that all of these cells, brown and beige, are sensitive to cold-induced signals from the sympathetic nervous system and $\beta$-adrenergic signaling. However, we do not have a clear view of what other neural pathways might innervate these nonclassical beige fat cells and bring about a thermogenic response. A thorough characterization of the innervation of these cells is warranted.

Another gap in our knowledge relates to the transcriptional basis for the development of both brown and beige fat cells. PRDM16 is certainly a major contributor to the development of both of these cells, but PRDM16 is expressed in brown and beige cells and does not appear to be the factor that distinguishes them. Since the DNAbinding activity of PRDM16 is not required for its browning effects, it is almost certainly acting as a transcriptional coregulator (Kajimura et al. 2008), docking on distinct DNA-binding transcription factors to drive the expression of distinct pathways. In some cases, such as nuclear receptors, the transcription factors themselves can offer opportunities for modulation of function in vivo.

That brown fat (in all of its forms) can modulate obesity and diabetes in experimental models must now be 
considered settled science. Ablation of brown fat with a toxigene driven by the UCP1 promoter or a knockout of the UCP1 gene both give mice an increased level of obesity and diabetes (Lowell et al. 1993; Feldmann et al. 2009). However, it should be noted that this results in defective function of both brown and beige fat and does not distinguish between the contributions of either individually. Many gain-of-function models also show a resistance to weight gain on a high-fat diet and resistance to type 2 diabetes. These include modulation of transcriptional components like FoxC2 and PRDM16, direct regulators of cAMP and cGMP signaling, and various members and regulators of the TGF $\beta$ family (see "Multiple Genetic Models Have Shown Modified Adaptive Thermogenesis Capacity in Brown/Beige Fat" and "Secreted Molecules That Activate BAT and/or Induce Beiging in WAT" above). However, again, either most of these studies do not distinguish between activation of classical brown and beige fat or these pathways work on both. One exception was the forced expression of PRDM16 in adipose tissues, which causes browning of the white fat and increased UCP1 expression but has no discernable effect on the classical brown fat (Seale et al. 2011). This model establishes that expansion of beige fat (and its function) can have an effect on fat accretion and glucose homeostasis.

Which of the two types of thermogenic fat would be best to target for treating obesity and diabetes in adult humans? It is now clear that human brown fat is actually composed of beige fat cells, so increasing the amount and thermogenic capacity of these cells might be more obviously accessible. While this is a relatively recently understood target, it is already clear that beige fat cells are a distinct cell type and that there is already one polypeptide hormone that preferentially activates beige fat: irisin. Since it is also clear that there are cell surface proteins that are expressed selectively on beige cells $(\mathrm{Wu}$ et al. 2012), it is very likely that there will be other natural or synthetic molecules that can elicit a useful response from beige fat cells. On the other hand, humans do have classical brown fat, at least as infants, and it is possible that these cells can be developed again and reactivated under certain conditions. Still, targeting beige fat might be somewhat simpler, at least at this early stage of our knowledge.

Because brown fat cells of all types can dissipate stored chemical energy as heat, the most obvious therapeutic application is in the treatment of obesity. Although preliminary calculations suggest that adult humans have enough brown or beige fat to make a difference in body weight if fully activated (Enerback 2010b), there are so many unknowns regarding amounts and activity states of brown fat in most humans that such calculations must be considered very approximate. It is also worth noting that activation of brown or beige fat has a powerful antidiabetic effect that might go beyond effects on obesity per se. This was apparent with transgenic expression of PRDM16, which caused browning of subcutaneous fat and a modest effect on body weight but a profound improvement in glucose tolerance. Whether this was due to preferential removal of glucose from blood by beige fat or secretion of an anti-diabetic beige adipokine remains to be determined. Certainly, the next decade will see massive efforts to use beige and brown fat to ameliorate human metabolic disease.

\section{Acknowledgments}

We thank M. Khandekar for helpful discussions. We apologize to those whom we were unable to reference due to space limitations. J.W. is supported by an NIH grant (1K01DK094824). P.C. is supported by a grant from the American Heart Association (11FTF7510004). This work is funded by the JPB Foundation and NIH grants (DK31405 and DK90861) to B.M.S.

\section{References}

Aherne W, Hull D. 1966. Brown adipose tissue and heat production in the newborn infant. I Pathol Bacteriol 91: 223234.

Ahmadian M, Abbott MJ, Tang T, Hudak CS, Kim Y, Bruss M, Hellerstein MK, Lee HY, Samuel VT, Shulman GI, et al. 2011. Desnutrin/ATGL is regulated by AMPK and is required for a brown adipose phenotype. Cell Metab 13: 739-748.

Alessi MC, Bastelica D, Morange P, Berthet B, Leduc I, Verdier M, Geel O, Juhan-Vague I. 2000. Plasminogen activator inhibitor 1 , transforming growth factor- $\beta 1$, and BMI are closely associated in human adipose tissue during morbid obesity. Diabetes 49: 1374-1380.

Auffret J, Viengchareun S, Carre N, Denis RG, Magnan C, Marie PY, Muscat A, Feve B, Lombes M, Binart N . 2012. Beige differentiation of adipose depots in mice lacking prolactin receptor protects against high-fat-diet-induced obesity. FASEB I 26: 3728-3737.

Au-Yong IT, Thorn N, Ganatra R, Perkins AC, Symonds ME. 2009. Brown adipose tissue and seasonal variation in humans. Diabetes 58: 2583-2587.

Bachman ES, Dhillon H, Zhang CY, Cinti S, Bianco AC, Kobilka BK, Lowell BB. 2002. $\beta A R$ signaling required for diet-induced thermogenesis and obesity resistance. Science 297: 843845.

Badman MK, Pissios P, Kennedy AR, Koukos G, Flier JS, Maratos-Flier E. 2007. Hepatic fibroblast growth factor 21 is regulated by PPAR $\alpha$ and is a key mediator of hepatic lipid metabolism in ketotic states. Cell Metab 5: 426-437.

Baron DM, Clerte M, Brouckaert P, Raher MJ, Flynn AW, Zhang $\mathrm{H}$, Carter EA, Picard MH, Bloch KD, Buys ES et al. 2012. In vivo noninvasive characterization of brown adipose tissue blood flow by contrast ultrasound in mice. Circ Cardiovasc Imaging 5: 652-659.

Bartelt A, Bruns OT, Reimer R, Hohenberg H, Ittrich $\mathrm{H}$, Peldschus K, Kaul MG, Tromsdorf UI, Weller H, Waurisch C, et al. 2011. Brown adipose tissue activity controls triglyceride clearance. Nat Med 17: 200-205.

Batista ML Jr, Neves RX, Peres SB, Yamashita AS, Shida CS, Farmer SR, Seelaender M. 2012. Heterogeneous time-dependent response of adipose tissue during the development of cancer cachexia. J Endocrinol 215: 363-373.

Bechtold DA, Sidibe A, Saer BR, Li J, Hand LE, Ivanova EA, Darras VM, Dam J, Jockers R, Luckman SM, et al. 2012. A role for the melatonin-related receptor GPR50 in leptin signaling, adaptive thermogenesis, and torpor. Curr Biol 22: 70-77.

Bianco AC. 2011. Minireview: Cracking the metabolic code for thyroid hormone signaling. Endocrinology 152: 3306-3311. 
Bordicchia M, Liu D, Amri EZ, Ailhaud G, Dessi-Fulgheri P, Zhang C, Takahashi N, Sarzani R, Collins S. 2012. Cardiac natriuretic peptides act via p38 MAPK to induce the brown fat thermogenic program in mouse and human adipocytes. J Clin Invest 122: 1022-1036.

Bostrom P, Wu J, Jedrychowski MP, Korde A, Ye L, Lo JC, Rasbach KA, Bostrom EA, Choi JH, Long JZ, et al. 2012. A PGC1- $\alpha$-dependent myokine that drives brown-fat-like development of white fat and thermogenesis. Nature 481: 463-468.

Boucher J, Mori MA, Lee KY, Smyth G, Liew CW, Macotela Y, Rourk M, Bluher M, Russell SJ, Kahn CR. 2012. Impaired thermogenesis and adipose tissue development in mice with fat-specific disruption of insulin and IGF-1 signalling. Nat Commun 3: 902.

Calo E, Quintero-Estades JA, Danielian PS, Nedelcu S, Berman $\mathrm{SD}$, Lees JA. 2010. $\mathrm{Rb}$ regulates fate choice and lineage commitment in vivo. Nature 466: $1110-1114$.

Cannon B, Nedergaard J. 2004. Brown adipose tissue: Function and physiological significance. Physiol Rev 84: 277-359.

Cao L, Choi EY, Liu X, Martin A, Wang C, Xu X, During MJ. 2011. White to brown fat phenotypic switch induced by genetic and environmental activation of a hypothalamicadipocyte axis. Cell Metab 14: 324-338.

Cawthorn WP, Scheller EL, MacDougald OA. 2012. Adipose tissue stem cells: The great WAT hope. Trends Endocrinol Metab 23: 270-277.

Cederberg A, Gronning LM, Ahren B, Tasken K, Carlsson P, Enerback S. 2001. FOXC2 is a winged helix gene that counteracts obesity, hypertriglyceridemia, and diet-induced insulin resistance. Cell 106: 563-573.

Chang Y, She ZG, Sakimura K, Roberts A, Kucharova K, Rowitch DH, Stallcup WB. 2012. Ablation of NG2 proteoglycan leads to deficits in brown fat function and to adult onset obesity. PloS ONE 7: e30637.

Chao PT, Yang L, Aja S, Moran TH, Bi S. 2011. Knockdown of NPY expression in the dorsomedial hypothalamus promotes development of brown adipocytes and prevents diet-induced obesity. Cell Metab 13: 573-583.

Chen D, Zhao M, Mundy GR. 2004. Bone morphogenetic proteins. Growth Factors 22: 233-241.

Chiang SH, Bazuine M, Lumeng CN, Geletka LM, Mowers J, White NM, Ma JT, Zhou J, Qi N, Westcott D, et al. 2009. The protein kinase IKK $\varepsilon$ regulates energy balance in obese mice. Cell 138: 961-975.

Christian M, Kiskinis E, Debevec D, Leonardsson G, White R, Parker MG. 2005. RIP140-targeted repression of gene expression in adipocytes. Mol Cell Biol 25: 9383-9391.

Cinti S. 2002. Adipocyte differentiation and transdifferentiation: Plasticity of the adipose organ. I Endocrinol Invest 25: 823835.

Clarke AR, Maandag ER, van Roon M, van der Lugt NM, van der Valk M, Hooper ML, Berns A, te Riele H. 1992. Requirement for a functional Rb-1 gene in murine development. Nature 359: 328-330.

Coste A, Louet JF, Lagouge M, Lerin C, Antal MC, Meziane H, Schoonjans K, Puigserver P, O'Malley BW, Auwerx J. 2008. The genetic ablation of SRC-3 protects against obesity and improves insulin sensitivity by reducing the acetylation of PGC-1 $\alpha$. Proc Natl Acad Sci 105: 17187-17192.

Coulter AA, Bearden CM, Liu X, Koza RA, Kozak LP. 2003. Dietary fat interacts with QTLs controlling induction of Pgc- $1 \alpha$ and Ucp1 during conversion of white to brown fat. Physiol Genomics 14: 139-147.

Cousin B, Cinti S, Morroni M, Raimbault S, Ricquier D, Penicaud L, Casteilla L. 1992. Occurrence of brown adipocytes in rat white adipose tissue: Molecular and morphological characterization. J Cell Sci 103: 931-942.

Czyzyk TA, Romero-Pico A, Pintar J, McKinzie JH, Tschop MH, Statnick MA, Nogueiras R. 2012. Mice lacking $\delta$-opioid receptors resist the development of diet-induced obesity. FASEB I 26: 3483-3492.

Cypess AM, Lehman S, Williams G, Tal I, Rodman D, Goldfine AB, Kuo FC, Palmer EL, Tseng YH, Doria A, et al. 2009. Identification and importance of brown adipose tissue in adult humans. N Engl J Med 360: 1509-1517.

Cypess AM, Chen YC, Sze C, Wang K, English J, Chan O, Holman AR, Tal I, Palmer MR, Kolodny GM, et al. 2012. Cold but not sympathomimetics activates human brown adipose tissue in vivo. Proc Natl Acad Sci 109: 10001-10005.

Dahle MK, Gronning LM, Cederberg A, Blomhoff HK, Miura N, Enerback S, Tasken KA, Tasken K. 2002. Mechanisms of FOXC2- and FOXD1-mediated regulation of the RI $\alpha$ subunit of cAMP-dependent protein kinase include release of transcriptional repression and activation by protein kinase $\mathrm{B} \alpha$ and cAMP. J Biol Chem 277: 22902-22908.

Doria A, Patti ME, Kahn CR. 2008. The emerging genetic architecture of type 2 diabetes. Cell Metab 8: 186-200.

Enerback S. 2010a. Brown adipose tissue in humans. Int J Obes (Lond) 34: S43-S46.

Enerback S. 2010b. Human brown adipose tissue. Cell Metab 11: 248-252.

Enerback S, Jacobsson A, Simpson EM, Guerra C, Yamashita H, Harper ME, Kozak LP. 1997. Mice lacking mitochondrial uncoupling protein are cold-sensitive but not obese. Nature 387: 90-94.

Fain JN, Tichansky DS, Madan AK. 2005. Transforming growth factor $\beta 1$ release by human adipose tissue is enhanced in obesity. Metabolism 54: 1546-1551.

Fedorenko A, Lishko PV, Kirichok Y. 2012. Mechanism of fattyacid-dependent UCP1 uncoupling in brown fat mitochondria. Cell 151: 400-413.

Feldmann HM, Golozoubova V, Cannon B, Nedergaard J. 2009. UCP1 ablation induces obesity and abolishes diet-induced thermogenesis in mice exempt from thermal stress by living at thermoneutrality. Cell Metab 9: 203-209.

Fisher FM, Kleiner S, Douris N, Fox EC, Mepani RJ, Verdeguer F, Wu J, Kharitonenkov A, Flier JS, Maratos-Flier E, et al. 2012. FGF21 regulates PGC- $1 \alpha$ and browning of white adipose tissues in adaptive thermogenesis. Genes Dev 26: 271-281.

Fournier B, Murray B, Gutzwiller S, Marcaletti S, Marcellin D, Bergling S, Brachat S, Persohn E, Pierrel E, Bombard F, et al. 2012. Blockade of the activin receptor IIb activates functional brown adipogenesis and thermogenesis by inducing mitochondrial oxidative metabolism. Mol Cell Biol 32: 2871-2879.

Fu L, John LM, Adams SH, Yu XX, Tomlinson E, Renz M, Williams PM, Soriano R, Corpuz R, Moffat B, et al. 2004. Fibroblast growth factor 19 increases metabolic rate and reverses dietary and leptin-deficient diabetes. Endocrinology 145: 2594-2603.

Fukui Y, Masui S, Osada S, Umesono K, Motojima K. 2000. A new thiazolidinedione, NC-2100, which is a weak PPAR- $\gamma$ activator, exhibits potent antidiabetic effects and induces uncoupling protein 1 in white adipose tissue of KKAy obese mice. Diabetes 49: 759-767.

Gesta S, Bluher M, Yamamoto Y, Norris AW, Berndt J, Kralisch S, Boucher J, Lewis C, Kahn CR. 2006. Evidence for a role of developmental genes in the origin of obesity and body fat distribution. Proc Natl Acad Sci 103: 6676-6681.

Gray SL, Dalla Nora E, Backlund EC, Manieri M, Virtue S, Noland RC, O'Rahilly S, Cortright RN, Cinti S, Cannon B, et al. 2006. Decreased brown adipocyte recruitment and 
thermogenic capacity in mice with impaired peroxisome proliferator-activated receptor (P465L PPAR $\gamma$ ) function. Endocrinology 147: 5708-5714.

Grobe JL, Grobe CL, Beltz TG, Westphal SG, Morgan DA, Xu D, de Lange WJ, Li H, Sakai K, Thedens DR, et al. 2010. The brain renin-angiotensin system controls divergent efferent mechanisms to regulate fluid and energy balance. Cell Metab 12: 431-442.

Guerra C, Koza RA, Yamashita H, Walsh K, Kozak LP. 1998. Emergence of brown adipocytes in white fat in mice is under genetic control. Effects on body weight and adiposity. I Clin Invest 102: 412-420.

Guilherme A, Virbasius JV, Puri V, Czech MP. 2008. Adipocyte dysfunctions linking obesity to insulin resistance and type 2 diabetes. Nat Rev Mol Cell Biol 9: 367-377.

Hallberg M, Morganstein DL, Kiskinis E, Shah K, Kralli A, Dilworth SM, White R, Parker MG, Christian M. 2008. A functional interaction between RIP140 and PGC- $1 \alpha$ regulates the expression of the lipid droplet protein CIDEA. Mol Cell Biol 28: 6785-6795.

Handschin C, Kobayashi YM, Chin S, Seale P, Campbell KP, Spiegelman BM. 2007. PGC-1 $\alpha$ regulates the neuromuscular junction program and ameliorates Duchenne muscular dystrophy. Genes Dev 21: 770-783.

Hansen JB, Jorgensen C, Petersen RK, Hallenborg P, De Matteis R, Boye HA, Petrovic N, Enerback S, Nedergaard J, Cinti S, et al. 2004. Retinoblastoma protein functions as a molecular switch determining white versus brown adipocyte differentiation. Proc Natl Acad Sci 101: 4112-4117.

Hatai S. 1902. On the presence in human embryos of an interscapular gland corresponding to the so-called hibernating gland of lower mammals. Anat Anz 21: 369-373.

Heaton JM. 1972. The distribution of brown adipose tissue in the human. J Anat 112: 35-39.

Herzig S, Long F, Jhala US, Hedrick S, Quinn R, Bauer A, Rudolph D, Schutz G, Yoon C, Puigserver P, et al. 2001. CREB regulates hepatic gluconeogenesis through the coactivator PGC-1. Nature 413: 179-183.

Himms-Hagen J, Melnyk A, Zingaretti MC, Ceresi E, Barbatelli G, Cinti S. 2000. Multilocular fat cells in WAT of CL-316243treated rats derive directly from white adipocytes. Am $I$ Physiol Cell Physiol 279: C670-C681.

Hondares E, Rosell M, Gonzalez FJ, Giralt M, Iglesias R, Villarroya F. 2010. Hepatic FGF21 expression is induced at birth via PPAR $\alpha$ in response to milk intake and contributes to thermogenic activation of neonatal brown fat. Cell Metab 11: 206-212.

Huh JY, Panagiotou G, Mougios V, Brinkoetter M, Vamvini MT, Schneider BE, Mantzoros CS. 2012. FNDC5 and irisin in humans: I. Predictors of circulating concentrations in serum and plasma and II. mRNA expression and circulating concentrations in response to weight loss and exercise. Metabolism 61: 1725-1738.

Inagaki T, Dutchak P, Zhao G, Ding X, Gautron L, Parameswara V, Li Y, Goetz R, Mohammadi M, Esser V, et al. 2007. Endocrine regulation of the fasting response by PPAR $\alpha$ mediated induction of fibroblast growth factor 21. Cell Metab 5: 415-425.

Jacks T, Fazeli A, Schmitt EM, Bronson RT, Goodell MA, Weinberg RA. 1992. Effects of an Rb mutation in the mouse. Nature 359: 295-300.

Jackson MF, Luong D, Vang DD, Garikipati DK, Stanton JB, Nelson OL, Rodgers BD. 2012. The aging myostatin null phenotype: Reduced adiposity, cardiac hypertrophy, enhanced cardiac stress response, and sexual dimorphism. I Endocrinol 213: 263-275.
Jakobsson A, Jorgensen JA, Jacobsson A. 2005. Differential regulation of fatty acid elongation enzymes in brown adipocytes implies a unique role for Elovl3 during increased fatty acid oxidation. Am J Physiol Endocrinol Metab 289: E517E526.

Jeong JK, Szabo G, Kelly K, Diano S. 2012. Prolyl carboxypeptidase regulates energy expenditure and the thyroid axis. Endocrinology 153: 683-689.

Jimenez-Preitner M, Berney X, Uldry M, Vitali A, Cinti S, Ledford JG, Thorens B. 2011. Plac8 is an inducer of C/EBP required for brown fat differentiation, thermoregulation, and control of body weight. Cell Metab 14: 658-670.

Jin W, Takagi T, Kanesashi SN, Kurahashi T, Nomura T, Harada J, Ishii S. 2006. Schnurri-2 controls BMP-dependent adipogenesis via interaction with Smad proteins. Dev Cell 10: 461-471.

Joe AW, Yi L, Natarajan A, Le Grand F, So L, Wang J, Rudnicki MA, Rossi FM. 2010. Muscle injury activates resident fibro/ adipogenic progenitors that facilitate myogenesis. Nat Cell Biol 12: 153-163.

Jonker JW, Suh JM, Atkins AR, Ahmadian M, Li P, Whyte J, He M, Juguilon H, Yin YQ, Phillips CT, et al. 2012. A PPAR $\gamma-$ FGF1 axis is required for adaptive adipose remodelling and metabolic homeostasis. Nature 485: 391-394.

Jung KM, Clapper JR, Fu J, D'Agostino G, Guijarro A, Thongkham D, Avanesian A, Astarita G, DiPatrizio NV, Frontini A, et al. 2012. 2-Aarachidonoylglycerol signaling in forebrain regulates systemic energy metabolism. Cell Metab 15: 299-310.

Kajimura S, Seale P, Tomaru T, Erdjument-Bromage H, Cooper MP, Ruas JL, Chin S, Tempst P, Lazar MA, Spiegelman BM. 2008. Regulation of the brown and white fat gene programs through a PRDM16/CtBP transcriptional complex. Genes Dev 22: 1397-1409.

Kajimura S, Seale P, Kubota K, Lunsford E, Frangioni JV, Gygi SP, Spiegelman BM. 2009. Initiation of myoblast to brown fat switch by a PRDM16-C/EBP- $\beta$ transcriptional complex. Nature 460: 1154-1158.

Kang S, Bajnok L, Longo KA, Petersen RK, Hansen JB, Kristiansen K, MacDougald OA. 2005. Effects of Wnt signaling on brown adipocyte differentiation and metabolism mediated by PGC-1 $\alpha$. Mol Cell Biol 25: 1272-1282.

Karamanlidis G, Karamitri A, Docherty K, Hazlerigg DG, Lomax MA. 2007. C/EBP $\beta$ reprograms white 3T3-L1 preadipocytes to a brown adipocyte pattern of gene expression. $I$ Biol Chem 282: 24660-24669.

Khanna A, Branca RT. 2012. Detecting brown adipose tissue activity with BOLD MRI in mice. Magn Reson Med 68: 1285-1290.

Kharitonenkov A, Shiyanova TL, Koester A, Ford AM, Micanovic R, Galbreath EJ, Sandusky GE, Hammond LJ, Moyers JS, Owens RA, et al. 2005. FGF-21 as a novel metabolic regulator. J Clin Invest 115: 1627-1635.

Kiefer FW, Vernochet C, O'Brien P, Spoerl S, Brown JD, Nallamshetty S, Zeyda M, Stulnig TM, Cohen DE, Kahn $\mathrm{CR}$, et al. 2012. Retinaldehyde dehydrogenase 1 regulates a thermogenic program in white adipose tissue. Nat Med 18: $918-925$.

Kim JK, Kim HJ, Park SY, Cederberg A, Westergren R, Nilsson D, Higashimori T, Cho YR, Liu ZX, Dong J, et al. 2005. Adipocyte-specific overexpression of FOXC2 prevents dietinduced increases in intramuscular fatty acyl CoA and insulin resistance. Diabetes 54: 1657-1663.

Klaman LD, Boss O, Peroni OD, Kim JK, Martino JL, Zabolotny JM, Moghal N, Lubkin M, Kim YB, Sharpe AH, et al. 2000. Increased energy expenditure, decreased adiposity, and 
tissue-specific insulin sensitivity in protein-tyrosine phosphatase 1B-deficient mice. Mol Cell Biol 20: 54795489.

Kleiner S, Mepani RJ, Laznik D, Ye L, Jurczak MJ, Jornayvaz FR, Estall JL, Chatterjee Bhowmick D, Shulman GI, Spiegelman BM. 2012. Development of insulin resistance in mice lacking PGC-1 $\alpha$ in adipose tissues. Proc Natl Acad Sci 109: 96359640.

Klingenspor M. 2003. Cold-induced recruitment of brown adipose tissue thermogenesis. Exp Physiol 88: 141-148.

Koncarevic A, Kajimura S, Cornwall-Brady M, Andreucci A, Pullen A, Sako D, Kumar R, Grinberg AV, Liharska K, Ucran JA, et al. 2012. A novel therapeutic approach to treating obesity through modulation of TGF $\beta$ signaling. Endocrinology 153: 3133-3146.

Konishi M, Mikami T, Yamasaki M, Miyake A, Itoh N. 2000. Fibroblast growth factor-16 is a growth factor for embryonic brown adipocytes. J Biol Chem 275: 12119-12122.

Koza RA, Hohmann SM, Guerra C, Rossmeisl M, Kozak LP. 2000. Synergistic gene interactions control the induction of the mitochondrial uncoupling protein (Ucp1) gene in white fat tissue. J Biol Chem 275: 34486-34492.

Krauss S, Zhang CY, Lowell BB. 2005. The mitochondrial uncoupling-protein homologues. Nat Rev Mol Cell Biol 6: 248-261.

Laplante M, Sell H, MacNaul KL, Richard D, Berger JP, Deshaies Y. 2003. PPAR- $\gamma$ activation mediates adipose depot-specific effects on gene expression and lipoprotein lipase activity: Mechanisms for modulation of postprandial lipemia and differential adipose accretion. Diabetes 52: 291-299.

Lean ME, James WP, Jennings G, Trayhurn P. 1986a. Brown adipose tissue in patients with phaeochromocytoma. Int $J$ Obes 10: 219-227.

Lean ME, James WP, Jennings G, Trayhurn P. 1986b. Brown adipose tissue uncoupling protein content in human infants, children and adults. Clin Sci (Lond) 71: 291-297.

Lecker SH, Zavin A, Cao P, Arena R, Allsup K, Daniels KM, Joseph J, Schulze PC, Forman DE. 2012. Expression of the irisin precursor FNDC5 in skeletal muscle correlates with aerobic exercise performance in patients with heart failure. Circ Heart Fail 5: 812-818.

Lee EY, Chang CY, Hu N, Wang YC, Lai CC, Herrup K, Lee WH, Bradley A. 1992. Mice deficient for $\mathrm{Rb}$ are nonviable and show defects in neurogenesis and haematopoiesis. Nature 359: 288-294.

Lee P, Greenfield JR, Ho KK, Fulham MJ. 2010. A critical appraisal of the prevalence and metabolic significance of brown adipose tissue in adult humans. Am I Physiol Endocrinol Metab 299: E601-E606.

Lee YH, Petkova AP, Mottillo EP, Granneman JG. 2012. In vivo identification of bipotential adipocyte progenitors recruited by $\beta 3$-adrenoceptor activation and high-fat feeding. Cell Metab 15: 480-491.

Leonardsson G, Steel JH, Christian M, Pocock V, Milligan S, Bell J, So PW, Medina-Gomez G, Vidal-Puig A, White R, et al. 2004. Nuclear receptor corepressor RIP140 regulates fat accumulation. Proc Natl Acad Sci 101: 8437-8442.

Lepper C, Fan CM. 2010. Inducible lineage tracing of Pax7descendant cells reveals embryonic origin of adult satellite cells. Genesis 48: 424-436.

Lerin C, Rodgers JT, Kalume DE, Kim SH, Pandey A, Puigserver P. 2006. GCN5 acetyltransferase complex controls glucose metabolism through transcriptional repression of PGC-1 $\alpha$. Cell Metab 3: 429-438.

Lidell MEBM, Leinhard OD, Heglind M, Elander L, Slawik M, Mussack T, Nilsson D, Romu T, Nuutila P, Virtanen KA, et al. 2013. Evidence for two types of brown adipose tissue in humans. Nat Med (in press).

Lin J, Wu H, Tarr PT, Zhang CY, Wu Z, Boss O, Michael LF, Puigserver $P$, Isotani E, Olson EN, et al. 2002. Transcriptional co-activator PGC-1 $\alpha$ drives the formation of slow-twitch muscle fibres. Nature 418: 797-801.

Lin J, Wu PH, Tarr PT, Lindenberg KS, St-Pierre J, Zhang CY, Mootha VK, Jager S, Vianna CR, Reznick RM, et al. 2004. Defects in adaptive energy metabolism with CNS-linked hyperactivity in PGC-1 $\alpha$ null mice. Cell 119: 121-135.

Lin J, Handschin C, Spiegelman BM. 2005. Metabolic control through the PGC-1 family of transcription coactivators. Cell Metab 1: 361-370.

Liu W, Singh R, Choi CS, Lee HY, Keramati AR, Samuel VT, Lifton RP, Shulman GI, Mani A. 2012. Low density lipoprotein (LDL) receptor-related protein 6 (LRP6) regulates body fat and glucose homeostasis by modulating nutrient sensing pathways and mitochondrial energy expenditure. I Biol Chem 287: 7213-7223.

Loncar D, Bedrica L, Mayer J, Cannon B, Nedergaard J, Afzelius BA, Svajger A. 1986. The effect of intermittent cold treatment on the adipose tissue of the cat. Apparent transformation from white to brown adipose tissue. I Ultrastruct Mol Struct Res 97: 119-129.

Loncar D, Afzelius BA, Cannon B. 1988a. Epididymal white adipose tissue after cold stress in rats. I. Nonmitochondrial changes. J Ultrastruct Mol Struct Res 101: 109-122.

Loncar D, Afzelius BA, Cannon B. 1988b. Epididymal white adipose tissue after cold stress in rats. II. Mitochondrial changes. I Ultrastruct Mol Struct Res 101: 199-209.

Louet JF, O'Malley BW. 2007. Coregulators in adipogenesis: What could we learn from the SRC (p160) coactivator family? Cell Cycle 6: 2448-2452.

Louet JF, Coste A, Amazit L, Tannour-Louet M, Wu RC, Tsai SY, Tsai MJ, Auwerx J, O'Malley BW. 2006. Oncogenic steroid receptor coactivator-3 is a key regulator of the white adipogenic program. Proc Natl Acad Sci 103: 17868-17873.

Lowell BB, S-Susulic V, Hamann A, Lawitts JA, Himms-Hagen J, Boyer BB, Kozak LP, Flier JS. 1993. Development of obesity in transgenic mice after genetic ablation of brown adipose tissue. Nature 366: 740-742.

Lu X, Ji Y, Zhang L, Zhang Y, Zhang S, An Y, Liu P, Zheng Y. 2012. Resistance to obesity by repression of VEGF gene expression through induction of brown-like adipocyte differentiation. Endocrinology 153: 3123-3132.

Ma S, Yu H, Zhao Z, Luo Z, Chen J, Ni Y, Jin R, Ma L, Wang P, $\mathrm{Zhu} Z$, et al. 2012. Activation of the cold-sensing TRPM8 channel triggers UCP1-dependent thermogenesis and prevents obesity. J Mol Cell Biol 4: 88-96.

Madar I, Isoda T, Finley P, Angle J, Wahl R. 2011. ${ }^{18}$ F-fluorobenzyl triphenyl phosphonium: A noninvasive sensor of brown adipose tissue thermogenesis. J Nucl Med 52: 808-814.

Mercader J, Ribot J, Murano I, Felipe F, Cinti S, Bonet ML, Palou A. 2006. Remodeling of white adipose tissue after retinoic acid administration in mice. Endocrinology 147: 5325-5332.

Mochizuki N, Shimizu S, Nagasawa T, Tanaka H, Taniwaki M, Yokota J, Morishita K. 2000. A novel gene, MEL1, mapped to $1 \mathrm{p} 36.3$ is highly homologous to the MDS1/EVI1 gene and is transcriptionally activated in $\mathrm{t}(1 ; 3)(\mathrm{p} 36 ; \mathrm{q} 21)$-positive leukemia cells. Blood 96: 3209-3214.

Mori H, Prestwich TC, Reid MA, Longo KA, Gerin I, Cawthorn WP, Susulic VS, Krishnan V, Greenfield A, Macdougald OA. 2012a. Secreted frizzled-related protein 5 suppresses adipocyte mitochondrial metabolism through WNT inhibition. I Clin Invest 122: 2405-2416. 
Mori M, Nakagami H, Rodriguez-Araujo G, Nimura K, Kaneda Y. 2012b. Essential role for miR-196a in brown adipogenesis of white fat progenitor cells. PLOS Biol 10: e1001314.

Moro C, Crampes F, Sengenes C, De Glisezinski I, Galitzky J, Thalamas C, Lafontan M, Berlan M. 2004. Atrial natriuretic peptide contributes to physiological control of lipid mobilization in humans. FASEB J 18: 908-910.

Moro C, Polak J, Hejnova J, Klimcakova E, Crampes F, Stich V, Lafontan M, Berlan M. 2006. Atrial natriuretic peptide stimulates lipid mobilization during repeated bouts of endurance exercise. Am J Physiol Endocrinol Metab 290: E864E869.

Mullen AC, Orlando DA, Newman JJ, Loven J, Kumar RM, Bilodeau S, Reddy J, Guenther MG, DeKoter RP, Young RA. 2011. Master transcription factors determine cell-type-specific responses to TGF- $\beta$ signaling. Cell 147: 565-576.

Nguyen KD, Qiu Y, Cui X, Goh YP, Mwangi J, David T, Mukundan L, Brombacher F, Locksley RM, Chawla A. 2011. Alternatively activated macrophages produce catecholamines to sustain adaptive thermogenesis. Nature 480: 104-108.

Nishikata I, Sasaki H, Iga M, Tateno Y, Imayoshi S, Asou N, Nakamura T, Morishita K. 2003. A novel EVIl gene family, MEL1, lacking a PR domain (MEL1S) is expressed mainly in $\mathrm{t}(1 ; 3)(\mathrm{p} 36 ; \mathrm{q} 21)$-positive AML and blocks G-CSF-induced myeloid differentiation. Blood 102: 3323-3332.

Nishio M, Yoneshiro T, Nakahara M, Suzuki S, Saeki K, Hasegawa M, Kawai Y, Akutsu H, Umezawa A, Yasuda K, et al. 2012. Production of functional classical brown adipocytes from human pluripotent stem cells using specific hemopoietin cocktail without gene transfer. Cell Metab 16: 394-406.

Ohno H, Shinoda K, Spiegelman BM, Kajimura S. 2012. PPAR $\gamma$ agonists induce a white-to-brown fat conversion through stabilization of PRDM16 protein. Cell Metab 15: 395-404.

Ortega-Molina A, Efeyan A, Lopez-Guadamillas E, MunozMartin M, Gomez-Lopez G, Canamero M, Mulero F, Pastor J, Martinez S, Romanos E, et al. 2012. Pten positively regulates brown adipose function, energy expenditure, and longevity. Cell Metab 15: 382-394.

Ouellet V, Routhier-Labadie A, Bellemare W, Lakhal-Chaieb L, Turcotte E, Carpentier AC, Richard D. 2011. Outdoor temperature, age, sex, body mass index, and diabetic status determine the prevalence, mass, and glucose-uptake activity of ${ }^{18}$ F-FDG-detected BAT in humans. I Clin Endocrinol Metab 96: 192-199.

Pan D, Fujimoto M, Lopes A, Wang YX. 2009. Twist-1 is a PPAR $\delta$-inducible, negative-feedback regulator of PGC- $1 \alpha$ in brown fat metabolism. Cell 137: 73-86.

Petrovic N, Walden TB, Shabalina IG, Timmons JA, Cannon B, Nedergaard J. 2010. Chronic peroxisome proliferator-activated receptor $\gamma$ (PPAR $\gamma$ ) activation of epididymally derived white adipocyte cultures reveals a population of thermogenically competent, UCP1-containing adipocytes molecularly distinct from classic brown adipocytes. J Biol Chem 285: 7153-7164.

Pfannenberg C, Werner MK, Ripkens S, Stef I, Deckert A, Schmadl M, Reimold M, Haring HU, Claussen CD, Stefan N. 2010. Impact of age on the relationships of brown adipose tissue with sex and adiposity in humans. Diabetes 59: 17891793.

Picard F, Gehin M, Annicotte J, Rocchi S, Champy MF, O'Malley BW, Chambon P, Auwerx J. 2002. SRC-1 and TIF2 control energy balance between white and brown adipose tissues. Cell 111: 931-941.

Pilegaard H, Saltin B, Neufer PD. 2003. Exercise induces transient transcriptional activation of the PGC- $1 \alpha$ gene in human skeletal muscle. I Physiol 546: 851-858.
Powelka AM, Seth A, Virbasius JV, Kiskinis E, Nicoloro SM, Guilherme A, Tang X, Straubhaar J, Cherniack AD, Parker MG, et al. 2006. Suppression of oxidative metabolism and mitochondrial biogenesis by the transcriptional corepressor RIP140 in mouse adipocytes. J Clin Invest 116: 125-136.

Puigserver P, Wu Z, Park CW, Graves R, Wright M, Spiegelman BM. 1998. A cold-inducible coactivator of nuclear receptors linked to adaptive thermogenesis. Cell 92: 829-839.

Qiang L, Wang L, Kon N, Zhao W, Lee S, Zhang Y, Rosenbaum M, Zhao Y, Gu W, Farmer SR, et al. 2012. Brown remodeling of white adipose tissue by SirT1-dependent deacetylation of Ppary. Cell 150: 620-632.

Quiros PM, Ramsay AJ, Sala D, Fernandez-Vizarra E, Rodriguez F, Peinado JR, Fernandez-Garcia MS, Vega JA, Enriquez JA, Zorzano A, et al. 2012. Loss of mitochondrial protease OMA1 alters processing of the GTPase OPA1 and causes obesity and defective thermogenesis in mice. EMBO J 31: 21172133.

Rasmussen AT. 1923. The so-called hibernating gland. J Morphol 38: 147-205.

Ricquier D, Nechad M, Mory G. 1982. Ultrastructural and biochemical characterization of human brown adipose tissue in pheochromocytoma. I Clin Endocrinol Metab 54: 803807.

Rodeheffer MS, Birsoy K, Friedman JM. 2008. Identification of white adipocyte progenitor cells in vivo. Cell 135: 240-249.

Rodriguez-Cuenca S, Pujol E, Justo R, Frontera M, Oliver J, Gianotti M, Roca P. 2002. Sex-dependent thermogenesis, differences in mitochondrial morphology and function, and adrenergic response in brown adipose tissue. I Biol Chem 277: 42958-42963.

Romanatto T, Roman EA, Arruda AP, Denis RG, Solon C, Milanski M, Moraes JC, Bonfleur ML, Degasperi GR, Picardi PK, et al. 2009. Deletion of tumor necrosis factor- $\alpha$ receptor 1 (TNFR1) protects against diet-induced obesity by means of increased thermogenesis. J Biol Chem 284: 36213-36222.

Rothwell NJ, Stock MJ. 1997. A role for brown adipose tissue in diet-induced thermogenesis. Obes Res 5: 650-656.

Ruas JL, White JP, Rao RR, Kleiner S, Brannan KT, Harrison BC, Greene NP, Wu J, Estall JL, Irving BA, et al. 2012. A PGC-1 $\alpha$ isoform induced by resistance training regulates skeletal muscle hypertrophy. Cell 151: 1319-1331.

Russell AP, Feilchenfeldt J, Schreiber S, Praz M, Crettenand A, Gobelet C, Meier CA, Bell DR, Kralli A, Giacobino JP, et al. 2003. Endurance training in humans leads to fiber type-specific increases in levels of peroxisome proliferator-activated receptor- $\gamma$ coactivator- 1 and peroxisome proliferator-activated receptor- $\alpha$ in skeletal muscle. Diabetes 52: 2874-2881.

Saltiel AR. 2012. Insulin resistance in the defense against obesity. Cell Metab 15: 798-804.

Samad F, Yamamoto K, Pandey M, Loskutoff DJ. 1997. Elevated expression of transforming growth factor- $\beta$ in adipose tissue from obese mice. Mol Med 3: 37-48.

Sanchez-Gurmaches J, Hung CM, Sparks CA, Tang Y, Li H, Guertin DA. 2012. PTEN loss in the Myf5 lineage redistributes body fat and reveals subsets of white adipocytes that arise from Myf5 precursors. Cell Metab 16: 348-362.

Sandri M, Lin J, Handschin C, Yang W, Arany ZP, Lecker SH, Goldberg AL, Spiegelman BM. 2006. PGC-1 $\alpha$ protects skeletal muscle from atrophy by suppressing FoxO3 action and atrophy-specific gene transcription. Proc Natl Acad Sci 103: 16260-16265.

Sarzani R, Paci VM, Dessi-Fulgheri P, Espinosa E, Rappelli A. 1993. Comparative analysis of atrial natriuretic peptide receptor expression in rat tissues. I Hypertens Suppl 11: S214S215. 
Sarzani R, Dessi-Fulgheri P, Paci VM, Espinosa E, Rappelli A. 1996. Expression of natriuretic peptide receptors in human adipose and other tissues. I Endocrinol Invest 19: 581-585.

Schulz TJ, Huang TL, Tran TT, Zhang H, Townsend KL, Shadrach JL, Cerletti M, McDougall LE, Giorgadze N, Tchkonia $\mathrm{T}$, et al. 2011. Identification of inducible brown adipocyte progenitors residing in skeletal muscle and white fat. Proc Natl Acad Sci 108: 143-148.

Scime A, Grenier G, Huh MS, Gillespie MA, Bevilacqua L, Harper ME, Rudnicki MA. 2005. Rb and p107 regulate preadipocyte differentiation into white versus brown fat through repression of PGC-1 $\alpha$. Cell Metab 2: 283-295.

Seale P, Kajimura S, Yang W, Chin S, Rohas LM, Uldry M, Tavernier G, Langin D, Spiegelman BM. 2007. Transcriptional control of brown fat determination by PRDM16. Cell Metab 6: 38-54.

Seale P, Bjork B, Yang W, Kajimura S, Chin S, Kuang S, Scime A, Devarakonda S, Conroe HM, Erdjument-Bromage $\mathrm{H}$, et al. 2008. PRDM16 controls a brown fat/skeletal muscle switch. Nature 454: 961-967.

Seale P, Conroe HM, Estall J, Kajimura S, Frontini A, Ishibashi J, Cohen P, Cinti S, Spiegelman BM. 2011. Prdm16 determines the thermogenic program of subcutaneous white adipose tissue in mice. J Clin Invest 121: 96-105.

Sellayah D, Bharaj P, Sikder D. 2011. Orexin is required for brown adipose tissue development, differentiation, and function. Cell Metab 14: 478-490.

Sengenes C, Berlan M, De Glisezinski I, Lafontan M, Galitzky J 2000. Natriuretic peptides: A new lipolytic pathway in human adipocytes. FASEB J 14: 1345-1351.

Sharp LZ, Shinoda K, Ohno H, Scheel DW, Tomoda E, Ruiz L, Hu H, Wang L, Pavlova Z, Gilsanz V, et al. 2012. Human BAT possesses molecular signatures that resemble beige/brite cells. PLOS ONE 7: e49452.

Shen JJ, Huang L, Li L, Jorgez C, Matzuk MM, Brown CW. 2009. Deficiency of growth differentiation factor 3 protects against diet-induced obesity by selectively acting on white adipose. Mol Endocrinol 23: 113-123.

Singh R, Xiang Y, Wang Y, Baikati K, Cuervo AM, Luu YK, Tang Y, Pessin JE, Schwartz GJ, Czaja MJ. 2009. Autophagy regulates adipose mass and differentiation in mice. $J$ Clin Invest 119: 3329-3339.

Smith RE, Horwitz BA. 1969. Brown fat and thermogenesis. Physiol Rev 49: 330-425.

Speakman JR, Selman C. 2003. Physical activity and resting metabolic rate. Proc Nutr Soc 62: 621-634.

Sun L, Xie H, Mori MA, Alexander R, Yuan B, Hattangadi SM, Liu Q, Kahn CR, Lodish HF. 2011. Mir193b-365 is essential for brown fat differentiation. Nat Cell Biol 13: 958965.

Teperino R, Amann S, Bayer M, McGee SL, Loipetzberger A, Connor T, Jaeger C, Kammerer B, Winter L, Wiche G, et al. 2012. Hedgehog partial agonism drives Warburg-like metabolism in muscle and brown fat. Cell 151: 414-426.

Timmons JA, Wennmalm K, Larsson O, Walden TB, Lassmann T, Petrovic N, Hamilton DL, Gimeno RE, Wahlestedt C, Baar $\mathrm{K}$, et al. 2007. Myogenic gene expression signature establishes that brown and white adipocytes originate from distinct cell lineages. Proc Natl Acad Sci 104: 4401-4406.

Tiraby C, Tavernier G, Lefort C, Larrouy D, Bouillaud F, Ricquier D, Langin D. 2003. Acquirement of brown fat cell features by human white adipocytes. I Biol Chem 278: 33370-33376.

Toh SY, Gong J, Du G, Li JZ, Yang S, Ye J, Yao H, Zhang Y, Xue B, Li Q, et al. 2008. Up-regulation of mitochondrial activity and acquirement of brown adipose tissue-like property in the white adipose tissue of fsp27 deficient mice. PloS ONE 3: e2890.

Trajkovski M, Ahmed K, Esau CC, Stoffel M. 2012. MyomiR133 regulates brown fat differentiation through Prdm16. Nat Cell Biol 14: 1330-1335.

Tseng YH, Kokkotou E, Schulz TJ, Huang TL, Winnay JN, Taniguchi CM, Tran TT, Suzuki R, Espinoza DO, Yamamoto Y, et al. 2008. New role of bone morphogenetic protein 7 in brown adipogenesis and energy expenditure. Nature 454: 1000-1004.

Tsoli M, Moore M, Burg D, Painter A, Taylor R, Lockie SH, Turner N, Warren A, Cooney G, Oldfield B, et al. 2012. Activation of thermogenesis in brown adipose tissue and dysregulated lipid metabolism associated with cancer cachexia in mice. Cancer Res 72: 4372-4382.

Tsukiyama-Kohara K, Poulin F, Kohara M, DeMaria CT, Cheng A, Wu Z, Gingras AC, Katsume A, Elchebly M, Spiegelman $\mathrm{BM}$, et al. 2001. Adipose tissue reduction in mice lacking the translational inhibitor 4E-BP1. Nat Med 7: 11281132 .

Uezumi A, Fukada S, Yamamoto N, Takeda S, Tsuchida K. 2010. Mesenchymal progenitors distinct from satellite cells contribute to ectopic fat cell formation in skeletal muscle. Nat Cell Biol 12: 143-152.

Uldry M, Yang W, St-Pierre J, Lin J, Seale P, Spiegelman BM. 2006. Complementary action of the PGC-1 coactivators in mitochondrial biogenesis and brown fat differentiation. Cell Metab 3: 333-341.

van Marken Lichtenbelt WD, Schrauwen P. 2011. Implications of nonshivering thermogenesis for energy balance regulation in humans. Am I Physiol Regul Integr Comp Physiol 301: R285-R296.

van Marken Lichtenbelt WD, Vanhommerig JW, Smulders NM, Drossaerts JM, Kemerink GJ, Bouvy ND, Schrauwen P, Teule GJ. 2009. Cold-activated brown adipose tissue in healthy men. N Engl J Med 360: 1500-1508.

Vegiopoulos A, Muller-Decker K, Strzoda D, Schmitt I, Chichelnitskiy E, Ostertag A, Berriel Diaz M, Rozman J, Hrabe de Angelis M, Nusing RM, et al. 2010. Cyclooxygenase-2 controls energy homeostasis in mice by de novo recruitment of brown adipocytes. Science 328: 1158-1161.

Vernochet C, Peres SB, Davis KE, McDonald ME, Qiang L, Wang H, Scherer PE, Farmer SR. 2009. C/EBP $\alpha$ and the corepressors CtBP1 and CtBP2 regulate repression of select visceral white adipose genes during induction of the brown phenotype in white adipocytes by peroxisome proliferatoractivated receptor $\gamma$ agonists. Mol Cell Biol 29: 47144728.

Vernochet C, Mourier A, Bezy O, Macotela Y, Boucher J, Rardin MJ, An D, Lee KY, Ilkayeva OR, Zingaretti CM, et al. 2012. Adipose-specific deletion of TFAM increases mitochondrial oxidation and protects mice against obesity and insulin resistance. Cell Metab 16: 765-776.

Vijgen GH, Bouvy ND, Teule GJ, Brans B, Schrauwen P, van Marken Lichtenbelt WD. 2011. Brown adipose tissue in morbidly obese subjects. PLOS ONE 6: e17247.

Vijgen GH, Bouvy ND, Teule GJ, Brans B, Hoeks J, Schrauwen P, van Marken Lichtenbelt WD. 2012. Increase in brown adipose tissue activity after weight loss in morbidly obese subjects. J Clin Endocrinol Metab 97: E1229-E1233.

Vila-Bedmar R, Lorenzo M, Fernandez-Veledo S. 2010. Adenosine $5^{\prime}$-monophosphate-activated protein kinase-mammalian target of rapamycin cross talk regulates brown adipocyte differentiation. Endocrinology 151: 980-992.

Vila-Bedmar R , Garcia-Guerra L, Nieto-Vazquez I, Mayor F Jr, Lorenzo M, Murga C, Fernandez-Veledo S. 2012. GRK2 
contribution to the regulation of energy expenditure and brown fat function. FASEB $J$ 26: 3503-3514.

Virtanen KA, Lidell ME, Orava J, Heglind M, Westergren R, Niemi T, Taittonen M, Laine J, Savisto NJ, Enerback S, et al. 2009. Functional brown adipose tissue in healthy adults. $N$ Engl J Med 360: 1518-1525.

Vosselman MJ, van der Lans AA, Brans B, Wierts R, van Baak MA, Schrauwen P, van Marken Lichtenbelt WD. 2012. Systemic $\beta$-adrenergic stimulation of thermogenesis is not accompanied by brown adipose tissue activity in humans. Diabetes 61: 3106-3113.

Walden TB, Hansen IR, Timmons JA, Cannon B, Nedergaard J. 2012. Recruited vs. nonrecruited molecular signatures of brown, 'brite,' and white adipose tissues. Am I Physiol Endocrinol Metab 302: E19-E31.

Wang H, Zhang Y, Yehuda-Shnaidman E, Medvedev AV, Kumar N, Daniel KW, Robidoux J, Czech MP, Mangelsdorf DJ, Collins S. 2008. Liver X receptor $\alpha$ is a transcriptional repressor of the uncoupling protein 1 gene and the brown fat phenotype. Mol Cell Biol 28: 2187-2200.

Wei W, Dutchak PA, Wang X, Ding X, Wang X, Bookout AL, Goetz R, Mohammadi M, Gerard RD, Dechow PC, et al. 2012. Fibroblast growth factor 21 promotes bone loss by potentiating the effects of peroxisome proliferator-activated receptor $\gamma$. Proc Natl Acad Sci 109: 3143-3148.

Wenz T, Rossi SG, Rotundo RL, Spiegelman BM, Moraes CT. 2009. Increased muscle PGC- $1 \alpha$ expression protects from sarcopenia and metabolic disease during aging. Proc Natl Acad Sci 106: 20405-20410.

Whittle AJ, Carobbio S, Martins L, Slawik M, Hondares E, Vazquez MJ, Morgan D, Csikasz RI, Gallego R, RodriguezCuenca S, et al. 2012. BMP8B increases brown adipose tissue thermogenesis through both central and peripheral actions. Cell 149: 871-885.

Wilson-Fritch L, Burkart A, Bell G, Mendelson K, Leszyk J, Nicoloro S, Czech M, Corvera S. 2003. Mitochondrial biogenesis and remodeling during adipogenesis and in response to the insulin sensitizer rosiglitazone. Mol Cell Biol 23: 1085-1094.

Wilson-Fritch L, Nicoloro S, Chouinard M, Lazar MA, Chui PC, Leszyk J, Straubhaar J, Czech MP, Corvera S. 2004. Mitochondrial remodeling in adipose tissue associated with obesity and treatment with rosiglitazone. J Clin Invest 114: 1281-1289.

Wright WS, Longo KA, Dolinsky VW, Gerin I, Kang S, Bennett $\mathrm{CN}$, Chiang SH, Prestwich TC, Gress C, Burant CF, et al. 2007. Wnt10b inhibits obesity in ob/ob and agouti mice. Diabetes 56: 295-303.

Wu J, Ruas JL, Estall JL, Rasbach KA, Choi JH, Ye L, Bostrom P, Tyra HM, Crawford RW, Campbell KP, et al. 2011. The unfolded protein response mediates adaptation to exercise in skeletal muscle through a PGC- $1 \alpha /$ ATF6 $\alpha$ complex. Cell Metab 13: 160-169.

Wu J, Bostrom P, Sparks LM, Ye L, Choi JH, Giang AH, Khandekar M, Virtanen KA, Nuutila P, Schaart G, et al. 2012. Beige adipocytes are a distinct type of thermogenic fat cell in mouse and human. Cell 150: 366-376.

Xu X, Ying Z, Cai M, Xu Z, Li Y, Jiang SY, Tzan K, Wang A, Parthasarathy S, He G, et al. 2011. Exercise ameliorates highfat diet-induced metabolic and vascular dysfunction, and increases adipocyte progenitor cell population in brown adipose tissue. Am I Physiol Regul Integr Comp Physiol 300: R1115-R1125.

Xue B, Coulter A, Rim JS, Koza RA, Kozak LP. 2005. Transcriptional synergy and the regulation of Ucp 1 during brown adipocyte induction in white fat depots. Mol Cell Biol 25: 8311-8322.
Xue B, Rim JS, Hogan JC, Coulter AA, Koza RA, Kozak LP. 2007. Genetic variability affects the development of brown adipocytes in white fat but not in interscapular brown fat. I Lipid Res 48: 41-51.

Yadav H, Rane SG. 2012. TGF- $\beta /$ Smad3 signaling regulates brown adipocyte induction in white adipose tissue. Front Endocrinol (Lausanne) 3: 35.

Yadav H, Quijano C, Kamaraju AK, Gavrilova O, Malek R, Chen W, Zerfas P, Zhigang D, Wright EC, Stuelten C, et al. 2011. Protection from obesity and diabetes by blockade of TGF$\beta /$ Smad3 signaling. Cell Metab 14: 67-79.

Yanase T, Fan W, Kyoya K, Min L, Takayanagi R, Kato S, Nawata H. 2008. Androgens and metabolic syndrome: Lessons from androgen receptor knock out (ARKO) mice. I Steroid Biochem Mol Biol 109: 254-257.

Ye L, Kleiner S, Wu J, Sah R, Gupta RK, Banks AS, Cohen P, Khandekar MJ, Bostrom P, Mepani RJ, et al. 2012. TRPV4 is a regulator of adipose oxidative metabolism, inflammation, and energy homeostasis. Cell 151: 96-110.

Yoshida M, Nosaka K, Yasunaga I, Nishikata I, Morishita K, Matsuoka M. 2004. Aberrant expression of the MEL1S gene identified in association with hypomethylation in adult T-cell leukemia cells. Blood 103: 2753-2760.

Young P, Arch JR, Ashwell M. 1984. Brown adipose tissue in the parametrial fat pad of the mouse. FEBS Lett 167: 10-14.

Zadravec D, Brolinson A, Fisher RM, Carneheim C, Csikasz RI, Bertrand-Michel J, Boren J, Guillou H, Rudling M, Jacobsson A. 2010. Ablation of the very-long-chain fatty acid elongase ELOVL3 in mice leads to constrained lipid storage and resistance to diet-induced obesity. FASEB J 24: 4366-4377.

Zamani N, Brown CW. 2011. Emerging roles for the transforming growth factor- $\beta$ superfamily in regulating adiposity and energy expenditure. Endocr Rev 32: 387-403.

Zhang Y, Li Y, Niepel MW, Kawano Y, Han S, Liu S, Marsili A, Larsen PR, Lee CH, Cohen DE. 2012. Targeted deletion of thioesterase superfamily member 1 promotes energy expenditure and protects against obesity and insulin resistance. Proc Natl Acad Sci 109: 5417-5422.

Zhou Z, Yon Toh S, Chen Z, Guo K, Ng CP, Ponniah S, Lin SC, Hong W, Li P. 2003. Cidea-deficient mice have lean phenotype and are resistant to obesity. Nat Genet 35: 49-56.

Zingaretti MC, Crosta F, Vitali A, Guerrieri M, Frontini A, Cannon B, Nedergaard J, Cinti S. 2009. The presence of UCP1 demonstrates that metabolically active adipose tissue in the neck of adult humans truly represents brown adipose tissue. FASEB J 23: 3113-3120.

Ziouzenkova O, Orasanu G, Sharlach M, Akiyama TE, Berger JP, Viereck J, Hamilton JA, Tang G, Dolnikowski GG, Vogel S, et al. 2007. Retinaldehyde represses adipogenesis and dietinduced obesity. Nat Med 13: 695-702. 


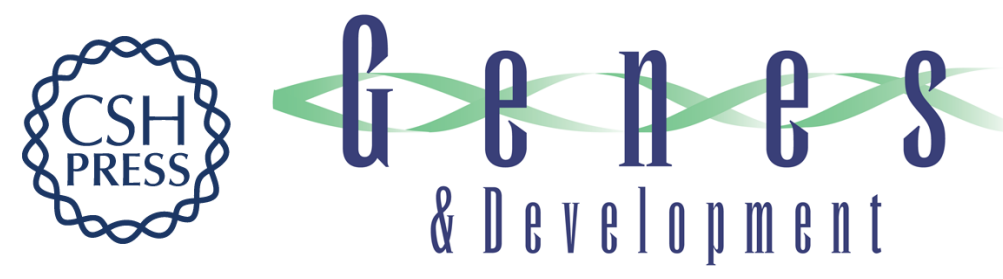

\section{Adaptive thermogenesis in adipocytes: Is beige the new brown?}

Jun Wu, Paul Cohen and Bruce M. Spiegelman

Genes Dev. 2013, 27:

Access the most recent version at doi:10.1101/gad.211649.112

References This article cites 202 articles, 55 of which can be accessed free at: http://genesdev.cshlp.org/content/27/3/234.full.html\#ref-list-1

License

Email Alerting Receive free email alerts when new articles cite this article - sign up in the box at the top Service right corner of the article or click here.

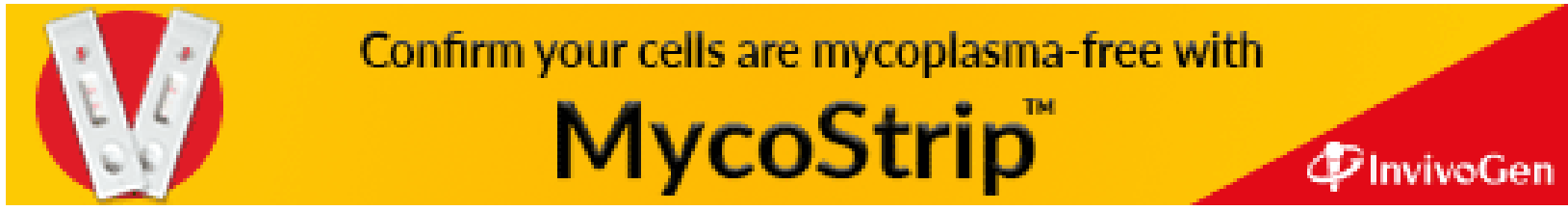

